PAUL L. JOSKOW

Massachusetts Institute of Technology

RICHARD SCHMALENSEE

Massachusetts Institute of Technology

\author{
NATALIA TSUKANOVA
}

Russian Privatization Center

\title{
Competition Policy in Russia during and after Privatization
}

IN SCALE, SCOPE, AND INTELLECTUAL INTEREST, the transformation of the command economies of the former Soviet Union (FSU) and many of its erstwhile allies is an extraordinary event. This essay is concerned with an important aspect of this historic process: the attempt to create a competitive market economy in Russia. Russia is still of considerable strategic importance, and it has the potential to be economically important as well. The Russian federation represented roughly 60-70 percent of the industrial production of the FSU, and it inherited impressive stocks of natural resources and human capital when the Soviet Union was dissolved in December 1991.

Unfortunately, Russia also inherited a crumbling economy. As the Soviet system collapsed, Russian output fell, and, even though most prices

Paul Joskow and Richard Schmalensee are grateful to Andrei Shleifer for getting them involved as advisors to the Russian Federation Committee on the Management of State Property in 1992; to Maxim Boycko, Jonathan Hay, and Charbell Ackermann for presenting them with challenging problems; and to David Ross, Ilya Segal, and Anna Chirkova for assisting them during their visits to Moscow and providing data analysis. All three authors are indebted to their discussants at Brookings, Andrei Shleifer and Janusz Ordover, and to Maxim Boycko, the editors of this volume, and audiences at MIT, Harvard, the Antitrust Division of the Department of Justice, and Brookings for unusually helpful comments. Much of the material discussed in this paper was developed through interviews conducted by the authors between mid-1992 and February 1994.

Editors' Note. Because of institutional constraints that make it difficult to obtain source material in Russia in a timely fashion, this paper was not subjected to the formal verification procedures established for research publications of the Brookings Institution. 
were nominally fixed, inflation exploded. Russian real gross domestic product (GDP) stagnated in 1989 and 1990 and declined about 9 percent in 1991, while the price level more than doubled in 1991. ${ }^{1}$ Many Russians blame the reforms that began only in early 1992 for this mess and its continuation, and political opposition to Russian economic reform has been strong and continuous. ${ }^{2}$

Of perhaps greater long-run importance, Russia also inherited industrial and institutional structures, along with relationships and allocations of functions among those structures, that are not suitable for a market economy. As we discuss, the so-called branch ministries and their successor organizations in the Soviet system performed many of the functions that firms perform in market economies. Creating a competitive Russian economy thus requires not only a broad shift from public to private ownership, but also a fundamental structural and functional realignment affecting a broad range of institutions. Those who would lose power in such a realignment have been firmly opposed to market-oriented economic reform since the Soviet era. They have been joined by those who were taught and continue to believe that the Russian economy is dominated by monopolists, as well as by those who fear radical and unpredictable change.

In the FSU, as in other command economies, political and economic spheres were closely intertwined. Subsidies to individual state enterprises, for instance, were the outcome of intensely political processes. Large enterprises controlled by influential ministries were able to command substantial resources regardless of the social value of their activities. They continued to do so even as the Soviet state crumbled and central planning collapsed. In Russia, this institutional inheritance has worked against both economic efficiency and political democracy. An important initial and continuing objective of Russian economic reform has thus necessarily been the depoliticization of economic activity. ${ }^{3}$

Russia also inherited an economy shaped by Soviet decisionmakers'

1. World Bank (1992, ch. 2).

2. As the final version of this paper was completed in April 1994, the macroeconomic situation remained uncertain. Hyperinflation had not yet emerged, as some had predicted it would. Concern continued, however, that the government would not be able to sustain reasonably tight monetary policies now that most reformers had been driven from the government. In addition, industrial production continued to decline and unemployment was increasing rapidly.

3. Boycko, Shleifer, and Vishny (1993) discuss this objective and its implications in detail. 
belief in economies of scale and specialization. Most descriptions of Soviet industrial organization emphasize the concentration of industrial activity in a small number of huge, vertically integrated organizations. Theory and experience make clear that Russians would be much better off if they could buy and sell in competitive markets than if their economy were to remain monopolized. Most characterizations of Russian industrial organization, however, suggest that many Russian industries are dominated by only one or two suppliers. Such a structural legacy could make the creation of competitive markets extremely difficult.

Why, with all of its economic and political problems, should Russia be concerned with monopoly problems and antitrust policies? There are two interrelated reasons. First, many Russian leaders believe that the "monopoly problem" is a very serious impediment to creating a market economy in Russia. Even reformers such as Grigory Yavlinsky have argued that price liberalization should not have taken place before the monopolies were "dismantled." ${ }_{4}$ Opponents of reform have used the fear of monopolies as an excuse for delay. Thus, purely as a political matter, a credible antimonopoly policy appears to be necessary to gather support for continuing economic reforms. Second, Russia has inherited an industrial structure that is not well adapted to efficient competitive markets. The problems here go beyond monopoly to include organizational and managerial imperfections that characterize Russian enterprises. Because the ultimate goal of privatization is to create a competitive market economy, the reform process should include policies for encouraging and supporting the necessary structural changes in firms and industries.

Some macroeconomists and trade specialists have asked why the structure of Russian industry is of concern since competition from abroad can provide competitive constraints on real or imagined Russian monopolies. Although this is true in principle, most observers believe that foreign competition cannot play as important a near-term procompetitive role in Russia as in some other economies in transition. In part this belief reflects Russia's enormous size (it covers eleven time zones!) and the unfortunate state of its transportation system. In part it also reflects the judgment of many that the ruble has been seriously undervalued and will not soon become a hard currency. And in part this belief reflects the political reality that important Russian industries will effectively seek protection from

4. “Russia: The Road to Ruin,'” Economist, January 29, 1994, p. 23. 
more efficient foreign competition. ${ }^{5}$ In any case, this paper focuses on competition within Russia, and we simply note here that (as in U.S. antitrust policy) actual and potential foreign competition must be considered in a full analysis of any particular market and that policies that would reduce impediments to foreign competition should be encouraged.

It has also been suggested that the historical structure of Russian industry and the enterprises emerging from it through the privatization process are irrelevant to competition in Russia beyond the very short run because the Russian capital stock is essentially worthless. If the economic reforms are successful, major changes in the structure of Russian industrial output, Russian industry, and Russian firms no doubt will occur. Unlike the former East Germany, however, Russia has low wages by Western standards and lacks a deep pocket from which to support unemployed workers. Most Russian industries face little competition from abroad and have experienced little foreign direct investment. That any of this will change in the near future seems unlikely. It is therefore probable that many Russian factories will continue for some time to use antiquated equipment and well-educated but low-wage workers to produce goods that Russian consumers can afford and will buy. Because domestic capital markets are likely to be slow to develop, foreign direct investment will likely be important in the ultimate modernization of the Russian capital stock, and joint ventures with existing Russian firms seem likely to be the primary vehicle for this investment. ${ }^{6}$ This implies that industries that are concentrated after privatization are likely to remain that way unless de novo foreign (or domestic) entry is unusually easy.

Because of Russia's institutional and structural inheritance from the FSU, competition policy there must march to two drummers. It must support efforts to depoliticize through privatization and through restructuring that eliminates Soviet economic institutions and their supporting antidemocratic political structures. It must also promote market competition to enhance static and dynamic efficiency in resource use. Promoting competition requires paying attention to market structures as they emerge

5. This has already happened. In late 1993, for instance, the leading Russian automaker, Avtovaz, threatened to cease production unless tariffs were raised substantially. The government responded with a hundredfold tariff increase in December, and Avtovaz announced substantial price increases a week later. In early January 1994, the Lada, a relatively small car based on an obsolete design, sold for about $\$ 13,000$.

6. On foreign entry into the Russian cigarette industry via joint ventures, see "A Rothmans Russia Plant,"' New York Times, December 22, 1993, p. D16. 
from privatization and are shaped thereafter and to the development of antitrust rules of conduct. As a result, it is impossible to evaluate competition policy issues in Russia without understanding the historical industrial and institutional legacy from which private firms and a market economy are evolving.

After discussing Russia's institutional and structural inheritance, we review Russian privatization, antitrust, and price control policies as they emerged early in 1992. We then discuss the operation of competition policy during privatization. How assets are transferred into private hands can have important implications for market competition as well as for the depoliticization of economic activity, so Russian competition policy during privatization necessarily involves both the antitrust authorities and the privatization agency.

Our discussion of the privatization process concentrates on the basic tensions that have emerged between depoliticization and deconcentration and how they have been resolved. In some settings, of course, these goals are complementary. For example, efforts to break up industrial and production associations or to resist creation of large, monopolistic holding companies and industrial conglomerates can serve both to promote market competition and to reduce the concentration of political power. In other settings, however, these objectives conflict. In particular, taking time to consider carefully actual and potential firm and market structures during privatization would necessarily slow depoliticization and thus put the reform process at risk. The difficulties of identifying and implementing efficient restructuring programs, along with the strenuous and continuing efforts of those who had power under the Soviet regime to resurrect old economic organizations and control structures under new names, have convinced Russian reformers not to follow the standard prescription to demonopolize before privatizing. ${ }^{7}$

Finally, we consider key challenges facing Russian competition policy after privatization. Some are familiar in the West, and some are oddly shaped shadows cast by Russian economic history. We find that many observers have overstated the structural monopoly problem in Russia and that antitrust and other economic policies can work effectively to promote competition. If suitable policies are implemented, Russia is not doomed to an economy of monopolists, with its unappealing economic and political

7. See Tirole (1991) for a clear presentation and defense of this prescription. 
implications. Sound policies can produce a relatively competitive Russian economy in the medium term, but there is no guarantee that such policies will soon be adopted.

\section{The Organization of Industry in the Soviet Union}

This section describes key features of industrial organization in the FSU as it existed in the late 1970s and early 1980s. The following section considers the changes in the Soviet economy instituted by Soviet leader Mikhail Gorbachev beginning in 1985 and their effects. These discussions are not comprehensive; they are limited to historical structural and behavioral arrangements that are important for understanding Russian privatization and competition policies. ${ }^{8}$

\section{The Hierarchical Structure of Soviet Industry}

Although the structure of the Soviet economy varied over time, it generally differed in fundamental ways from the structures of developed market economies. ${ }^{9}$ It is important to understand these differences, because, as we discuss below, strong forces continue to press for restoration of Soviet economic structures, albeit under new labels.

Each industrial sector can be thought of as a three- to five-tier hierarchy beneath the primary state planning and price setting entities: the State Planning Committee (Gosplan), the State Committee on Prices (Goskomtsen), the Ministry for the Distribution of Material Production (Gosnab), and the State Bank (Gosbank). At the top of each industrial hierarchy was a union or union-republic branch ministry with primary responsibility for a particular industrial sector and for dealing with the main organs of state planning. For example, separate branch ministries

8. Good information about the detailed characteristics of Russian enterprises and associations is very difficult to obtain. Of course, data available to Western scholars were fairly limited during the Soviet period, and U.S. economists, management experts, and businesspeople had limited contact with Russian enterprises. It also appears, however, that few Russian economists had broad knowledge about the structure and behavior of Russian industry. Officials responsible for individual industrial sectors seem to have had a monopoly on detailed information about enterprise structure and business relationships.

9. Much of the discussion in this subsection is based on Freris (1984, pp. 1-48), Hewett (1988, pp. 94-250), and Spulber (1991, pp. 9-29). 
were responsible for designing and constructing heavy machinery, light machinery, agricultural machinery, and home appliances, and for railroads, electricity, and truck transportation, among others.

Industrial OR BRANCH Ministries. Producing entities under the control of all-union ministries were run directly from Moscow. Unionrepublic ministries, however, had offices both in Moscow and in the republic involved (for example, Russia or Ukraine), and orders could come from either office. In the early 1980 s roughly fifty branch ministries were responsible for manufacturing, energy, communications, and transportation sectors at the union and union-republic level, nine of which were in the military-industrial complex. Underneath the union or union-republic ministries were often symmetrical ministries in each republic. These ministries, however, were responsible primarily for strictly local enterprises that did not deal directly with Moscow. Further disaggregation to agencies at the regional level also occurred for some goods and services. Each branch ministry was responsible for negotiating the planning targets for its industry, obtaining the material and financial resources required to fulfill these targets, and inducing the enterprises within its hierarchy to meet these targets.

In the mid-1980s the union and union-republic ministries controlled roughly 80 percent of the 46,000 industrial enterprises located throughout the FSU, of which about 25,000 were in Russia. ${ }^{10}$ The smaller local enterprises ( 20 percent of total enterprises) were controlled by regional and local authorities. " The number of state enterprises remained almost constant from the early 1960 s to the mid-1980s, but the fraction with more than 500 employees more than doubled. ${ }^{12}$ Table 1 provides a

10. World Bank (1992, p. 83), and International Monetary Fund (IMF) (1991, p. 287).

11. Russia, or, more properly, particularly in this context, the Russian Federation, inherited a complex structure of more than eighty regional governments from the FSU. The Russian Federation used to be divided into autonomous republics, autonomous oblasts, autonomous okrugs, oblasts, and krais; the cities of Moscow and St. Petersburg had special status. The former autonomous republics are now simply called republics, and most of the autonomous oblasts have become republics as well. Republics and autonomous oblasts have more autonomy in economic decisionmaking than the other regional entities, all of which have approximately the same relationship with the federal authorities. Republican and regional governments performed important economic functions under the FSU, in part because textbook-style, fully centralized planning was simply not workable.

12. Spulber (1991, p. 174, table 9-1). 


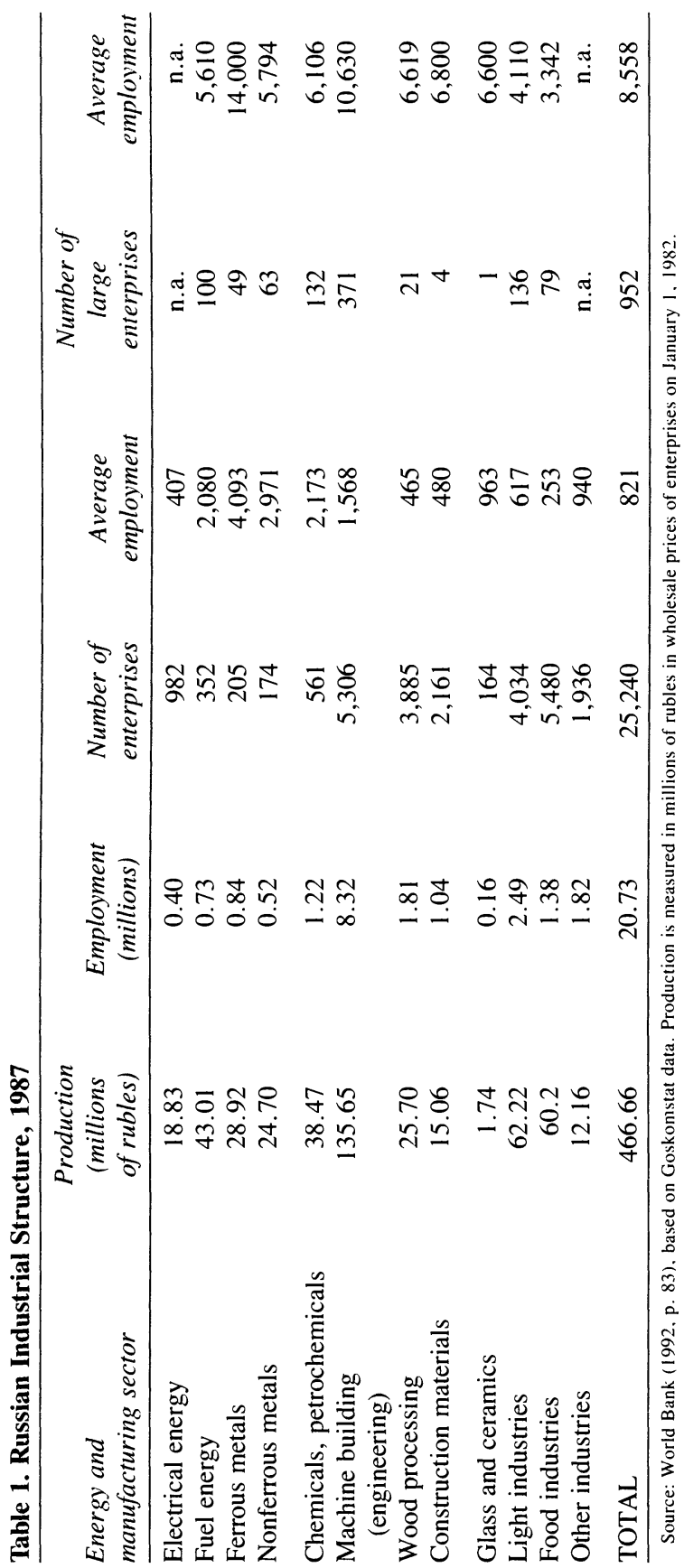


breakdown of production and employment for the Russian manufacturing and energy sectors in 1987. The machine building industries accounted for about one-third of Russian manufacturing production, while in the United States the production of industrial machinery and equipment accounts for less than 10 percent of manufacturing output.

ENTERPRISES. Until the Brezhnev reforms of the early 1970s, branch ministries at the union and republic levels dealt directly with individual industrial "enterprises" within their branch, assigning each enterprise a production plan and coordinating activities among them. Each of these enterprises had an " independent' management responsible for meeting its planning targets, its own books of financial accounts, and various financial responsibilities regarding wages and bonuses, reinvestment of profits, and payments for various social services provided to workers (such as housing, canteens, health clinics, and day care centers).

Production and Industrial Associations. In the early 1970s the government promoted the development of two types of associations as intermediate levels of the command and control hierarchy located between the ministries and the individual enterprises. ${ }^{13}$ The first type, called production associations, consisted of individual enterprises producing horizontally and vertically related products, along with associated research and development (R\&D) establishments. These associations were intended to integrate their member enterprises in order to obtain the benefits of economies of scale, increase specialization of production, improve coordination and enhance flexibility among enterprises; encourage R\&D and its application; and reduce information and transactions costs by reducing the number of entities with which the ministries had to deal. In fact, the extent of horizontal and vertical integration achieved varied considerably. In some associations the level of coordination among enterprises was high, ultimately culminating in merger, while in others the relationships were looser, and individual enterprises in the association retained both their legal identities and some operational independence. By 1980 production associations and their constituent enterprises accounted for about half of industrial production in the FSU. ${ }^{14}$

13. See, generally, Freris (1984, pp. 5-11), Kroll (1991, p. 148), and Hewett (1988, p. 245-50).

14. Freris (1984, pp. 4-10), Hewett (1988, p. 248), and Spulber (1991, pp. 17576). 
The other type of association created in the early 1970s was the industrial association, which consisted of a much larger number of individual enterprises and production associations producing related products and inputs and which was organized at the union, republic, or regional levels. The industrial associations were designed to replace the departments within branch ministries (glavks) that had responsibilities for individual sets of closely related enterprises and production associations, to rationalize overlapping responsibilities between departments within each industrial ministry, and to decentralize the supervision of the enterprises and production associations by creating supervisory and coordination organizations separate from the ministry and closer to the producing units. The associations were intended to improve industrial performance by moving those responsible for planning and coordination closer to the enterprises and further from the branch ministries. The branch ministries resisted losing their authority to the industrial associations, however, and the planned structural changes were implemented slowly and incompletely. Many observers argue that the industrial associations achieved neither the expected efficiencies nor any significant independence from their ministries. ${ }^{15}$

In part because the associations did not improve performance, a new set of reforms in 1979 stopped the pressures for the creation of more production and industrial associations. The fraction of industrial production accounted for by production and industrial associations stopped growing after $1980 .{ }^{16}$ Nevertheless, the creation of production associations generally reduced the independence of the associated legal entities called enterprises. Indeed, the term "enterprise", came to be used loosely to refer to individual legal entities (which are legally "enterprises"') as well as to production associations made up of several legal enterprises, and even to larger administrative aggregations of enterprises formed by individual branch ministries. Moreover, these different notions of what constituted an enterprise in the FSU encompassed organizational structures with wide variations in actual managerial independence from other enterprises within their respective ministries. ${ }^{17}$

Later reform efforts in 1979 and the early 1980s did not change the basic hierarchical structure and authority relationships within the in-

15. See, for example, Kroll (1991, p. 148) and Spulber (1991, p. 165).

16. Freris (1984, pp. 4-10), and Spulber (1991, p. 175).

17. Hewett (1988, p. 251, n. 50). 
dustrial sector. Thus, as the Gorbachev reform process began in 1985, the industrial branch ministries had enormous power within their respective sectors. They selected enterprise managers and closely managed planning targets, resource availability, flows of capital, $R \& D$, product introductions, and the distribution of output by the production associations and enterprises. They coordinated vertical and horizontal relationships among associations and enterprises within their direct control and under the control of other ministries. Thus many of the managerial functions normally found within firms in market economies were performed in the branch ministries, not in the enterprises.

\section{Industrial Organization at the Enterprise and Production}

Association Level

In the Soviet era, the relevant ministries aggressively pursued concentration of production in a relatively small number of individual enterprises and production associations as well as a high degree of product specialization within enterprises. Rather than producing a wide range of related products, each enterprise produced a very narrow range of products. Both goals reflected a belief that all industrial production processes were characterized by important economies of scale at all imaginable output levels. ${ }^{18}$ In addition, having only a few producing entities simplified the tasks of the central planning, pricing, and supply and distribution ministries.

In pursuit of these objectives, reforms during the 1950s reduced the number of state-owned enterprises in the FSU from more than 200,000 to roughly 45,000 and eliminated very small cooperative establishments. ${ }^{19}$ The reforms of the early 1970s that brought many enterprises into production and industrial associations were an attempt to concentrate industrial production further and to enhance product specialization without loss of economies of scope.

Specialization and Scale. The Russian truck industry illustrates the results of the pursuit of concentration and specialization during the

18. This widespread view is apparently the foundation for the assertion that "Russia has a very large number of natural monopolies,"' which we heard frequently from Russian officials.

19. Spulber (1991, pp. 173-75). 
Soviet period. ${ }^{20}$ Russia has five truck production complexes, each with production facilities concentrated primarily in a single city. ${ }^{21}$ Table 2 shows not only that these complexes each produced different types of trucks, but also that Russian industrial production declined before the reforms. Each truck manufacturer was a separate enterprise or production association made up of "independent" enterprises under one of the industrial branch ministries.

It is often argued that Russian industrial enterprises and production associations tend to be large by Western standards. This is sometimes referred to as the legacy of a strategy of "gigantism" that began under Stalin. ${ }^{22}$ Enterprises with 1,000 or more workers accounted for nearly 75 percent of industrial output in the FSU in 1987, for instance, and enterprises with more than 10,000 employees accounted for about 20 percent. ${ }^{23}$ The very largest Russian enterprises had more than 100,000 employees.

In fact, the largest Russian enterprises are not unusually large compared with U.S. firms. According to the Census of Manufactures, the top fifty U.S. manufacturing companies had average employment of more than 60,000 U.S. workers in 1987, and the next fifty had average employment of more than 20,000. Together the top two hundred manufacturing corporations (almost all of which had at least 10,000 U.S. employees) accounted for 43 percent of value added in manufacturing in 1987. The very largest U.S. corporations had more than 200,000 employees. ${ }^{24}$

20. The information in this paragraph was taken primarily from Holt (1993, ch. 9). For a recent view of the truck company KAMAZ, stressing its extensive involvement with Western firms, see Richard W. Stevenson, "Russian Truck Maker Becomes a Lab for U.S. Deals," New York Times, January 16, 1994, p. F5.

21. The truck maker ZIL, which was privatized in 1993 through the voucher auction process, is something of an exception. It had subsidiaries at ten sites around the country. They were privatized separately, but virtually all their production is still supplied to ZIL. ZIL also produces refrigerators and microwave ovens, for which there is a brisk demand; see Alexander Gordeyev, "Truck Crisis Worsens as ZIL Sends Workers Home,' Moscow Times, January 13, 1994, p. 1.

22. See Katz (1977).

23. Kroll (1991, pp. 1, 147), and Spulber (1991, p. 174).

24. These numbers were computed from U.S. Department of Commerce, 1987 Census of Manufactures, Concentration Ratios in Manufacturing (MC87-S-6), p. 6-3, table 2; combined with manufacturing employment drawn from the 1987 Census of Manufactures, General Summary, p. 1-2, table 1. See also Edmund Faltermayer, "'The 'Fortune' 
Table 2. Russian Truck Production

\begin{tabular}{lrrr}
\hline Company, truck type & $\begin{array}{c}\text { Capacity } \\
\text { (thousands) }\end{array}$ & $\begin{array}{c}1990 \\
\text { Production }\end{array}$ & $\begin{array}{r}1991 \\
\text { Production }\end{array}$ \\
\hline ZIL, Moscow & 200.7 & 184.2 & 158.1 \\
ZIL 4331 (5 ton 4x2 general purpose) & 5.0 & 4.0 & 4.4 \\
ZIL 157 (6x6, off-road) & 15.0 & 10.3 & 0.8 \\
ZIL 133 (5 ton 4x2, long platform) & 10.0 & 3.9 & 3.3 \\
ZIL 131 (4 ton, 6x6 military being converted & 50.0 & 49.8 & 43.3 \\
$\quad$ to civilian use) & & & \\
ZIL 130 (4x2 general purpose) & 120.7 & 116.2 & 106.3 \\
GAZ, Nizhny Novgorod & 294.0 & 249.3 & 199.5 \\
GAZ 52 (2.5 ton) & 54.0 & 55.1 & 21.9 \\
GAZ 5312 (4.5 ton agricultural use) & 200.0 & 154.0 & 139.5 \\
GAZ 66 (2.5-3.0 ton general purpose) & 40.0 & 40.2 & 38.1 \\
URALAZ, Miass & 31.6 & 31.6 & 31.4 \\
URAL 4320 (5 ton 6x6 general purpose) & 26.0 & 26.2 & 25.9 \\
URAL 5557 (5 ton 6x6 agricultural dumper) & 5.6 & 5.4 & 5.5 \\
UAZ, Ulianovsk & 42.8 & 40.8 & 38.1 \\
UAZ (0.8 ton 4x4 light truck) & 42.8 & 40.8 & 38.1 \\
KAMAZ, Naberezhnye Chelny & 150.0 & 116.4 & 102.7 \\
KAMAZ 5320 (8 ton 6x4 general purpose) & 30.0 & 32.0 & 28.0 \\
KAMAZ 4310 (7 ton 6x6 agricultural & 40.0 & 18.4 & 14.0 \\
dumper) & & & \\
KAMAZ 5511 (6 ton 6x4 agricultural & 40.0 & 43.0 & 40.0 \\
dumper) & & & \\
KAMAZ 5410 (11 ton 6x6 heavy truck) & 40.0 & 23.0 & 20.7 \\
\hline
\end{tabular}

Source: Holt (1993, p. 185).

What is striking about the size distribution of Russian enterprises is the relative lack of small manufacturing enterprises. ${ }^{25}$ In the United States more than 300,000 companies are engaged in manufacturing. In Russia, where small companies have been discouraged historically in the interest of scale economies and planning efficiencies, manufacturing was concentrated in roughly 25,000 enterprises before the restructurings that began in 1990 .

Large Russian enterprises are structured quite differently from large U.S. firms. The latter generally have multiple establishments and facilities at many different locations around the country and often abroad.

500 Listing of Top U.S. Industrial Corporations: Poised for a Comeback,' Fortune, April 19, 1993, p. 222.

25. This is stressed by Brown, Ickes, and Ryterman (1993). 
In Russia enterprises tend to locate all their facilities in or near a single city and often operate a single large, integrated production complex. Branch ministries and industrial associations historically performed the coordination functions for enterprises producing similar products across the country that are performed within large national multiestablishment firms in the United States.

This physical and organizational structure creates some potentially difficult problems for implementing a demonopolization strategy. Breaking up existing enterprises into multiple, viable, competing firms may also be difficult because much of the information necessary to effect workable separations is possessed by people in the branch ministries and enterprises who are unlikely to want to reveal it to those who might want to break them up. ${ }^{26}$

The functional structure of Russian industry also suggests that Russian enterprises might be more appropriately treated as the equivalent of establishments, or plants, in the United States: producing facilities located on a single site. If U.S. establishment data are compared with Russian enterprise data, the gigantism story reemerges. According to the Census of Manufactures, only about 1,700 manufacturing establishments had more than 1,000 U.S. employees in 1987, and these establishments accounted for just over 30 percent of value added in manufacturing. In the FSU more than 7,000 industrial enterprises had more than 1,000 employees in 1987, and they accounted for about 75 percent of industrial production.

The U.S. data do not reveal the number of manufacturing establishments with more than 5,000 employees, and it appears that there simply were no U.S. establishments with more than 10,000 employees. The 421 U.S. establishments with more than 2,500 employees accounted for about 18 percent of value added in manufacturing in 1987. Thus, if Russian enterprises are viewed as being more like U.S. establishments than like U.S. firms, they are very large indeed. ${ }^{27}$

Vertical Integration. Because of infirmities of Soviet planning that made it difficult for enterprises controlled by different ministries

26. One cannot help but recall Judge Wyzanski's dilemma in the United Shoe Machinery case. How was he to break up a company whose facilities were all located at a single site in Beverly, Massachusetts?

27. Spulber (1991, p. 174), and U.S. Department of Commerce, 1987 Census of Manufactures, General Summary, p. 1-99, table 4). 
to rely on each other for supplies, the branch ministries pursued policies of self-sufficiency in material input (autarky) that largely ignored scale economies. ${ }^{28}$ The result was a high degree of vertical integration. ${ }^{29}$ Thus, for instance, a large truck manufacturing complex in Moscow (ZIL) was fully vertically integrated "producing everything from raw casings, to final machined components, to truck assembly, to finishings, " and the norm was for producing entities to own their own trucks and avoid reliance on trucking enterprises. ${ }^{30}$

Many branch ministries established enterprises to build machinery and equipment required by other producing enterprises for which they were responsible, rather than purchasing from enterprises under machinery or equipment branch ministries. Many ministries developed their own construction enterprises, repair enterprises, food distribution facilities, and even farms. Enterprises, production associations, and ministries often produced their own raw materials, such as cement and timber, and even consumer products, such as washing machines and refrigerators, for their workers. Finally, enterprises often provided their workers with housing, food supplies, canteens, day care centers, health care facilities, and other social services. ${ }^{31}$

The precise mode of vertical integration varied considerably. Production at the various levels of the vertical chain may have been within a single enterprise, it may have been undertaken by separate enterprises within a production association, or it may have been accomplished through separate enterprises coordinated by a branch ministry. In any event, if extensive vertical integration were preserved through privatization, it could represent, in combination with high levels of concentration in product markets, a serious barrier to entry of new firms and expansion of existing firms into new product lines.

Product- and Industry-level Concentration. In light of the goals of Soviet industrial policy and the structure of Soviet enterprises, it is not surprising that Russian product-level data show very high levels

28. Hewett (1988, pp. 170-76) provides an extensive discussion with numerous examples.

29. IMF (1991, p. 293).

30. Lawrence and others (1990, p. 104).

31. We were told that the best hospital in the city of Vladimir was owned by a local production association. About 25 percent of the employees of the regional railroads are not engaged in work related to railway operations; most of these employees work in schools, hospitals, and restaurants that serve railway employees; see Holt (1993, p. 62). 
Table 3. Numbers of Producers for Products in Selected Industries

Percentage

\begin{tabular}{lrrrrrr}
\hline & Number of & \multicolumn{5}{c}{ Number of producers } \\
\cline { 3 - 7 } Branch & products & \multicolumn{1}{c}{$I$} & $2-3$ & $4-6$ & $7-10$ & More than 10 \\
\hline Machine building & 5,885 & 87.0 & 7.8 & 2.7 & 1.0 & 1.5 \\
Metallurgy & 208 & 27.9 & 28.4 & 20.7 & 9.6 & 13.4 \\
Chemicals and wood & 1,225 & 46.7 & 27.6 & 13.1 & 5.1 & 7.5 \\
Construction & 90 & 30.0 & 28.9 & 12.2 & 17.8 & 11.1 \\
\hline
\end{tabular}

Source: Kroll (1991, p. 145).

Table 4. Selected Product Monopolies and Near Monopolies

\begin{tabular}{llr}
\hline Product & \multicolumn{1}{c}{$\begin{array}{c}\text { Producer and } \\
\text { location }\end{array}$} & $\begin{array}{c}\text { Percentage of } \\
\text { total production }\end{array}$ \\
\hline Sewing machines & Shveinaya Association, Podolsk & 100 \\
Washing machines & Elektrobytpribor Factory, Kirov & 90 \\
Trolley buses & Uritsky Factory, Engels & 97 \\
Forklift trucks & Autopogruzhchik Association, & 87 \\
& Kharkov & \\
Diesel locomotives & Industrial Association, & 95 \\
Electric locomotives & Voroshilovgrad & 70 \\
Tram rails & Electric Locomotive Plant, & 100 \\
Concrete mixers & Novocherkassk & 93 \\
Road-building cranes & Integrated Steel Works, Kuznetsk & 75 \\
Locomotive cranes & Integrated Mill, Tuva Works & 100 \\
Deep-oil-well sucker rods & Sverdlovsk Plant, Sverdlovsk & 87 \\
Oil sucker rod pumps & Engineering Plant, Kirov & 100 \\
Hoists for coal mines & Ochesk Engineering Plant, Ochesk & 100 \\
Cooking equipment & Dzerzhinsky Engineering Plant, Baku & 100 \\
& City Coal Machinery Plant, Donetsk & \\
\hline
\end{tabular}

Source: The Economist, August 11, 1990, p. 67.

of concentration. ${ }^{32}$ Table 3 provides data based on studies by Russian economists for several thousand individual products or product classes, and table 4 presents some information for fourteen "monopoly" products. Many industrial products in the FSU were produced by only a single enterprise, and a majority of products were produced by three or fewer enterprises. This concentration of production was most pronounced for enterprises associated with the machine-building ministries

32. See, for instance, Kroll (1991, esp. p. 144), IMF (1991, p. 287), and World Bank (1992, p. 82). 
(where defense-related enterprises are heavily represented) and lowest in light industry and consumer products. ${ }^{33}$

The data in tables 3 and 4 and other figures reported for concentration in Russia or the FSU are based on much narrower product market definitions than are commonly used by Western economists in rough descriptions of market structures, however. Most Russian data appear to be at about the seven-digit level under the U.S. Standard Industrial Classification (SIC) system, rather than the three- or four-digit level of aggregation that is most often employed in this context. (There are about 11,000 seven-digit products under the SIC system and 459 fourdigit industries.) It is far from obvious, as we discuss below, that the narrow product market definitions on which analyses of concentration in Russia have traditionally relied are useful for assessing market power in the future, because it is not clear that historical patterns of plantspecific specialization will persist.

To shed light on the implications of changes in those patterns, we assisted the Committee on the Management of State Property (Goskomimuschestvo, or GKI) in developing a seller concentration data set drawn from 1991 Goskomstat (federal statistical agency) data for Russian industrial enterprises, but at a higher level of aggregation roughly equivalent to the four-digit SIC industry level. This data set and its construction are discussed in more detail in the appendix.

Table 5 displays the frequency distributions of the shares of national industry sales accounted for by the largest enterprise $\left(\mathrm{CR}_{1}\right)$ and the largest four enterprises $\left(\mathrm{CR}_{4}\right)$ for each industry in our data set. Only 3 percent of these industries are textbook monopolies, and only 5.5 percent have leading enterprises that account for 70 percent or more of sales. Only 0.07 percent of the enterprises in the database account for 70 percent or more of the sales in their respective industries. The largest enterprise accounts for 30 percent or more of sales in only 24 percent of these industries. Thus, at the four-digit level of aggregation the vast majority of Russian industries are not dominated by a single firm with a very large share of sales.

33. These figures actually understate the historical degree of concentration, as they do not aggregate products produced by enterprises that belonged to the same production association. Nor do they account for the fact that "independent" enterprises collectively producing a wide range of related products were generally under the control of a single branch ministry. 
Table 5. Distributions of Russian Industry-Level Concentration Ratios

\begin{tabular}{lcc}
\hline & \multicolumn{2}{c}{$\begin{array}{c}\text { Number of industries when concentration is } \\
\text { measured by }\end{array}$} \\
\cline { 2 - 3 } Percentage of industry sales & $\begin{array}{c}\text { Share of largest } \\
\text { firm }\left(C R_{1}\right)\end{array}$ & $\begin{array}{c}\text { Share of largest } \\
\text { four firms }\left(C R_{4}\right)\end{array}$ \\
\hline Less than 10.0 & 48 & 6 \\
$10.0-19.9$ & 69 & 14 \\
$20.0-34.9$ & 61 & 48 \\
$35.0-49.9$ & 25 & 39 \\
$50.0-59.9$ & 12 & 25 \\
$60.0-69.9$ & 6 & 21 \\
$70.0-79.9$ & 5 & 27 \\
$80.0-89.9$ & 2 & 11 \\
$90.0-100.0$ & 6 & 43 \\
Total number of industries & 234 & 234 \\
\hline
\end{tabular}

Source: Computations based on GKI concentration database.

Table 5 also shows that sales by the largest four enterprises exceed 90 percent for about 18 percent of Russian industries and exceed 70 percent for 35 percent of these industries. By comparison, about 1.5 percent of the 459 U.S. four-digit manufacturing industries had sales of 90 percent or greater concentrated in just four firms in 1987, while 8.3 percent had sales of 70 percent or greater concentrated in four firms. Thus, Russian industry is clearly more concentrated than U.S. industry at the four-digit level. At the same time, 46 percent of the Russian manufacturing industries in our data set have four-firm concentration ratios values below 50 percent. Furthermore, as discussed in the appendix, the upper tail in the Russian concentration data has been fattened by the presence of several industries that are clearly much narrower than the corresponding four-digit U.S. industries.

Table A-1 in the appendix provides detailed information for Russian industries that appear to be reasonably well matched to specific U.S. four-digit industries, and table 6 contains some summary statistics for several sets of these four-digit industries grouped into two-digit manufacturing sectors. The Russian four-firm concentration ratios are, on average, roughly 12 percent (5.5 percentage points) higher than the corresponding U.S. industries. The U.S. and Russian concentration ratios are significantly correlated, but the relation is not close $(r=$ $0.28)$. The incidence of very high concentration $\left(\mathrm{CR}_{4}\right)$ is not dramati- 
Table 6. Average Industry Concentration Ratios in Various Manufacturing Sectors

\begin{tabular}{lcc}
\hline $\begin{array}{l}\text { Manufacturing sector } \\
\text { two-digit SIC code) }\end{array}$ & $\begin{array}{c}\text { Average U.S. } \\
C R_{4}\end{array}$ & $\begin{array}{c}\text { Average Russian } \\
C_{4}\end{array}$ \\
\hline Food and kindred products (20) & 54.8 & 28.5 \\
Chemicals, allied products (28) & 52.7 & 59.5 \\
Stone, clay, and glass (32) & 62.4 & 53.0 \\
Primary metals (33) & 51.2 & 62.0 \\
Industrial machinery and equipment (35) & 33.1 & 50.9 \\
Transportation equipment (37) & 57.2 & 52.8 \\
Average for all industries in table A-1 & 46.8 & 52.3 \\
\hline
\end{tabular}

Source: Computed from information in table A-1.

cally greater in Russia than in the United States. Indeed, the United States has significantly higher average concentration levels in the food and kindred products sector, probably reflecting the importance of nationally advertised and distributed brands, in contrast to the local distribution of generic food products in Russia. ${ }^{34}$ Russian concentration is significantly higher in industrial machinery and equipment, primary metals, and chemicals and allied products, reflecting Russian concentration of production in large industrial complexes in these sectors.

Of course, these national concentration data do not account for the possible existence of regional geographic markets. When multiple Russian enterprises produced the same products, each tended to distribute its production in a single region or contiguous set of regions. As a result, many enterprises (especially in light industry, which was relatively unconcentrated at the national level) developed localized relationships with wholesale and retail outlets and did not distribute their output nationally. Postprivatization levels of concentration will depend on how rapidly patterns of geographic and product specialization are transformed by supply substitution and entry from those inherited from the FSU to patterns more typical of Western economies. This, in turn, depends on the ability of individual enterprises to change product mix, on the entry and expansion of new enterprises, and on obstacles to such a transformation-particularly problems of distribution and transportation.

Moreover, Russian concentration may be overstated because intermediate goods production within vertically integrated enterprises is less

34. On this general relation, see Sutton (1991) and Schmalensee (1992). 
likely to be counted than in the U.S. data. Because branch ministries' policies of material input self-sufficiency have led Russian industry to be highly vertically integrated, exclusion of this sort of capacity is likely to represent a significant bias. Even though Russian enterprises may now consume all of this unmeasured output internally, the corresponding capacities represent a potential future source of competition. And, as we discuss below, the privatization program has successfully encouraged spinoffs of divisions of enterprises into separate private firms, and many of these have represented vertical disintegration.

The Military-industrial Complex. The statistics presented above may also overstate Russian concentration because they do not cover all production of civilian products by enterprises that constituted the military-industrial complex. Although information on these enterprises is sparse, it is clear that they have produced a wide range of civilian products both for use by the military and government agencies (and their workers) and for distribution to civilian enterprises and the public. Table 7, which displays some information on the production of civilian goods by these enterprises in 1980 and 1988, shows that the militaryindustrial complex accounts for a significant fraction of production of some civilian products. Furthermore, many facilities used to produce military products could, in principle, be readily converted to production of civilian products such as trucks, engines, ovens, and machine tools. Thus, the enterprises in the military-industrial complex represent a potential source of new entry and increased output that is not fully reflected in the published industrial statistics.

\section{The Distribution System}

In developed market economies, manufacturers often compete directly for the patronage of wholesale and retail distributors. In Russia, these sectors will play an important role in determining the ability of manufacturing firms to compete by moving into new product and geographic markets. Unfortunately, Russia inherited a distribution system quite ill suited to a modern market economy. ${ }^{35}$

Producing entities in Russia were generally not vertically integrated downstream into wholesale or retail trade. Instead, the distribution of

35. See Spulber (1991, ch. 11), and IMF (1991, ch. V.2) for informative general discussions. 
Table 7. Civilian Products Produced by the Soviet Military-Industrial Complex

\begin{tabular}{lrr}
\hline & \multicolumn{2}{c}{ Percentage of total USSR output produced } \\
\cline { 2 - 3 } Product & 1980 & 1990 \\
\hline Tractors & 15 & 14 \\
Rail freight cars & 27 & $\mathrm{n} . \mathrm{a}$. \\
Tramcars & 60 & $\mathrm{n} . \mathrm{a}$. \\
Passenger cars & 10 & 11 \\
Motor scooters & 100 & $53^{\mathrm{a}}$ \\
Refrigerators & 47 & 93 \\
Washing machines & 35 & 66 \\
Vacuum cleaners & 33 & 69 \\
Tape recorders & 90 & $<100$ \\
Television sets & 100 & 100 \\
Radios & 100 & 100 \\
Video recorders & 100 & 100 \\
Clocks and watches & 10 & 15 \\
Cameras & 100 & 100 \\
Furniture & 2 & 4 \\
Bicycles & 30 & 43 \\
Medical equipment & n.a. & 80 \\
NC machine tools & n.a. & 14 \\
Food industry equipment & n.a. & 80 \\
Communications equipment & n.a. & 100 \\
\hline
\end{tabular}

Source: Cooper (1986, 1991).

a. Includes cycles.

raw materials and producer goods was accomplished through a complex set of planning arrangements involving administrative agencies at every level of government. Nominally, Gosnab was responsible for organizing the distribution of material inputs among enterprises, but important operational responsibilities were often delegated to departments within the branch ministries and their counterparts at the republic and regional levels. ${ }^{36}$

A second, separate system of wholesale and retail trade was responsible for distributing goods and services to consumers. The Ministry of Trade had primary command responsibility, although much of the direct responsibility for running wholesale and retail establishments was delegated to local authorities. ${ }^{37}$ At the regional and local levels, wholesale

36. Spulber (1991, pp. 208-10).

37. The distribution of agricultural products was governed by a third set of agencies and command and control arrangements that we will not discuss here; some ministries (such as railroads) had their own distribution systems; and a cooperative distribution 
and retail distribution establishments were not linked in any direct way to specific producers and received goods from multiple factories for sale. For example, the bread-baking industry in Moscow and Leningrad had about a dozen large wholesale bakeries from which bread was delivered, usually by specialized trucking firms, to specified retail shops, where the bread was sold to consumers. Each retail shop might get deliveries of bread (unbranded, of course) from several bakeries within a few days.

Marxist thought viewed marketing, advertising, retail trade, and related services as unproductive activities and of inferior social importance to the production of goods. As a result Russia has a very undeveloped retail sector, with many fewer retail sales and service outlets per capita (in aggregate and by sector) than are in Western countries or even in Eastern Europe. ${ }^{38}$ As all visitors observe, public restaurants are notably scarce. Retail margins were consciously kept low, averaging roughly 10 percent, compared with roughly 30 percent for the retail sector in Western Europe and the United States. The retail service sector was especially poorly developed, and a shadow, or underground, economy grew up to provide necessary services, such as auto repair, to consumers. Because many consumer goods were in short supply, retailers generally did not need to spend money on advertising, marketing, or services to sell the goods that they were allocated.

\section{The Transportation Sector}

In the latter part of the nineteenth century, U.S. railroads increased competition in many sectors by linking previously isolated local and regional markets. The creation of national markets led, in turn, to the creation of national firms. ${ }^{39}$ Whether the Russian transportation system will play a similar role in the transformation of that economy is unfortunately unclear. ${ }^{40}$

Russia's size, the composition and geographic distribution of pro-

network served rural areas. See, generally, IMF (1991, pp. 31-32), Boston Consulting Group (BCG) (1993), and Spulber (1991, ch. 11).

38. On the issues addressed in this paragraph, see IMF (1991, pp. 32-39), Spulber (1991, pp. 214-20), and BCG (1993).

39. See, generally, Chandler (1977).

40. Unless otherwise indicated, this discussion is based on Holt (1993, pp. 25, 59, and 67). 
duction in the FSU, and massive subsidization of energy consumption led to heavy reliance on long-distance transportation services. The volume of freight transport services (measured in ton-kilometers) per dollar of GDP in the FSU was far higher than in other countries-roughly five times higher than in the United States. Excluding pipeline transportation of petroleum products, the railroad system carries about 90 percent of the ton-kilometers of freight in Russia, compared with about 40 percent in the United States and 10 percent in Western Europe. (Pipeline transport of petroleum accounts for about 25 percent of total freight movements in ton-kilometers.) Most of the rest moves by truck; river and sea transport are relatively unimportant. It has been estimated that the rail system of the FSU carried half the world's ton-miles of rail freight traffic.

Before reform began in the late 1980 s, the Ministry of Railways was responsible for all railroads (freight and passenger) and production of important inputs, including rail cars and switches. The railroad sector is still structured and operated to move large quantities of bulk commodities (such as coal, iron ore, and steel) and heavy machinery long distances. The average length of haul is more than 900 kilometers, although about 18 percent of rail freight moves less than 100 kilometers. (We have been told that some products are regularly shipped by rail from one side of Moscow to the other.) The rail system is poorly adapted to quick delivery of a broad range of "light" manufactured products and consumer goods. Shipments must typically be scheduled months in advance, and even then pickup and delivery dates are uncertain. The breakup of the FSU has apparently caused major problems for the railroad system, which, along with its system of specialized suppliers, was planned and operated as an integrated whole for the entire FSU.

Trucks are used primarily to move products from production centers to railroads, from farms to distribution centers, and within urban areas; there is very little long-distance truck traffic. The average length of haul is only about 20 kilometers. Reflecting branch ministries' autarky policies, about 80 percent of truck freight relies on vehicles owned by shipping enterprises or production associations; the common carrier (for-hire) trucking sector is quite small. The road system is extremely poor and cannot sustain a large increase in heavy intercity truck traffic without significant expansion and upgrading.

Before reform began, the for-hire trucking sector was the responsi- 
bility of the Ministry of Automotive Services, which controlled 78 subsidiary organizations and 2,500 separate enterprises. Many of these enterprises supplied trucking services; others provided repair, booking, freight forwarding, consignment, repair parts manufacture, and other services related to trucking. Each region had its own trucking association, with 35-40 enterprises providing freight transportation and related services as well as bus and taxi services. Our understanding is that the individual enterprises within the trucking associations tended to specialize in particular types of trucks and trucking services (bread delivery is an important example) and relied on the association for general services such as bookings and scheduling, garaging, and repair services. ${ }^{41}$

The limitations of the FSU's transportation sector seem to have reinforced the tendency toward regional autarky and reliance on a small number of nearby suppliers and customers. St. Petersburg apparently neither imports nor exports paint, for instance, and clothing seems to have been handled in large part at the regional level. Vegetables are generally consumed in the region in which they are produced; storage (often of poor quality) in Russia substitutes for transportation in most developed market economies. ${ }^{42}$ These patterns will inevitably change to some extent with privatization: a clothing factory in Vladimir that served a mainly regional market in the Soviet era now exports a large fraction of its production. But how fast regional markets merge into national markets seems likely to depend importantly on the speed with which the transportation system can be modernized. That, in turn, is likely to depend primarily on the speed with which the railroad ministry can be reformed and the road system improved.

\section{The Breakdown of Central Control}

The highly centralized governance structure described above persisted until about 1987. The first two years of the Gorbachev reforms (1985-86) were devoted mainly to efforts to streamline and strengthen

41. The International Finance Corporation (IFC) (1993) description of Nizhny Novgorod is consistent with our interviews in Moscow, St. Petersburg, and Vladimir.

42. BCG (1993). 
the central planning process. ${ }^{43} \mathrm{~A}$ set of superministries was created to oversee and rationalize the behavior of related groups of previously independent industrial branch ministries, and industrial concentration was encouraged through mergers and the expansion of closely knit production associations.

In addition, in order to strengthen direct ties between the branch ministries and the enterprises and production associations, the industrial associations, whose power had begun to wane in the early 1980s, were eliminated. Industrial departments in the branch ministries often assumed the authorities of the industrial associations, but when the branch ministerial structure began to disintegrate after 1990, industrial associations reemerged as trade associations.

\section{Decentralization and Its Consequences}

In the 1987-89 period the Gorbachev government appears to have changed course and embarked on a program designed to decentralize decisionmaking authority. ${ }^{44}$ The role of Gosplan and Gosnab in directing the allocation of key products was to be shifted to the more decentralized wholesale trade system, and the authority to appoint enterprise managers was shifted from branch ministries to workers' collectives. Reforms in most Russian industries also increased managers' control over investment decisions.

In this same period, the central planning system, governed by Gosplan, was gradually replaced with a system of state orders, through which the state contracted for a particular percentage of enterprise output at a specified price in return for guaranteed delivery of the necessary inputs at controlled prices. Enterprises had to arrange for inputs necessary to produce beyond state orders, but such production could be sold to other enterprises or consumers at controlled prices or bartered. The proportion of production subject to state orders was even supposed to decline rapidly from 1988 to 1990 , but state orders in fact accounted for most industrial output through 1990.

On balance, although the center continued to exercise predominant control through a variety of mechanisms, the authority of enterprises to

43. See, generally, Hewett (1988, pp. 335-40), and Spulber (1991, pp. 268-69, 279).

44. See, generally, Hewett (1988, pp. 322-33) and IMF (1991, pp. 296-300). 
make their own production, financing, and wage decisions had begun to increase noticeably by 1990 . The 1990 Law on Enterprises accelerated this trend, giving managers more freedom to make decisions independent of worker collectives, allowing enterprises to participate in new joint stock companies, and allowing mergers and the formation of associations as corporate entities. Laws facilitating the creation of small enterprises and joint-stock companies were also passed in 1990. Collectively, these changes substantially increased both the de facto power of enterprise managers and the control rights of local and regional governments. ${ }^{45}$

In addition these changes stimulated a process of so-called spontaneous, or nomenklatura, privatization, which accelerated in $1991 .{ }^{46}$ This process took several forms, all of which represented local assertions of control rights in response to the center's withdrawal of control. Initially, workers or managers simply diverted profits to their own use. This led to the transfer of assets to new private ventures at very low prices and to the creation of de facto independent ventures within existing enterprises. The other main process was worker-management buyouts of assets at their book values, which, because of the rapid inflation that began in the late 1980s, were much less than market values. These buyouts generally involved payments to local governments and, sometimes, central government ministries. Unfortunately, the scope of this pre-1992 privatization process is not well documented, although a large number of enterprises, especially smaller enterprises in light industry and services, appear to have gained a sort of de facto private status by 1992 .

As the branch ministry system began to collapse in 1990-91, the ministries became increasingly unable to create and maintain links among enterprises, their suppliers, and customers. For the first time, enterprise and association managers had to perform this function. Because managers were not selected for the necessary skills, there is no reason to believe that managerial authority was in the right hands during this often chaotic transitional period. During interviews managers have often stated that the 1990-91 period was difficult because they often had to develop on their own the necessary complex systems of input

45. See, for instance, World Bank (1992, p. 84).

46. See World Bank (1992, p. 85) and Cooper (1991, pp. 53-59). 
supply and sales relationships with other enterprises as the capabilities of the branch ministries deteriorated. Although prices were not liberalized until early 1992, markets of various sorts began to evolve earlier through barter and other exchange relationships.

\section{The Rise of Trade Associations}

The final collapse of the power of the branch ministries was caused by two laws passed by the Russian parliament in 1991-92 ("Law on the Budget System', and "Law on Tax on Profits"), which provided that all enterprises were subject to the same taxes and were free to use their surpluses as they saw fit. By 1992 almost no branch ministries were left in Russia; most of them had transformed themselves into trade associations. The management of these associations was often the same as in the former branch ministries ${ }^{47}$ Typically, an association contained the enterprises that had been controlled by a branch ministry or one of its constituent departments. For example, 90 percent of the enterprises in the former Ministry of Construction Materials became members of the Construction Materials Association. There were exceptions, however: when the Ministry for Construction of Heavy Machinery for the Energy Industry broke up at the end of 1990, nine associations were formed in its place. Collectively, the trade associations represented both an attempt by the bureaucrats from the branch ministries to retain their positions of authority and a safety net for the enterprises (workers and managers) that had fairly suddenly been cut loose from the central planning system without a working system for arranging inputs and distributing outputs.

Table 8 provides information on thirteen important trade associations as of July 1992. Comparison with table 1 indicates that these associations alone covered more than 25 percent of enterprises and more than 40 percent of workers in Russian industry. Table 8 also reveals that by the summer of 1992, before the formal privatization program had begun, nearly 2,000 enterprises, some of which were divisions that had separated from established enterprises, had been spontaneously privatized through a variety of (presumably both legal and illegal) means involving leasing, transformation into joint stock companies, and "other.' Had the government not moved quickly with a formal privat-

47. World Bank (1992, p. 84). 


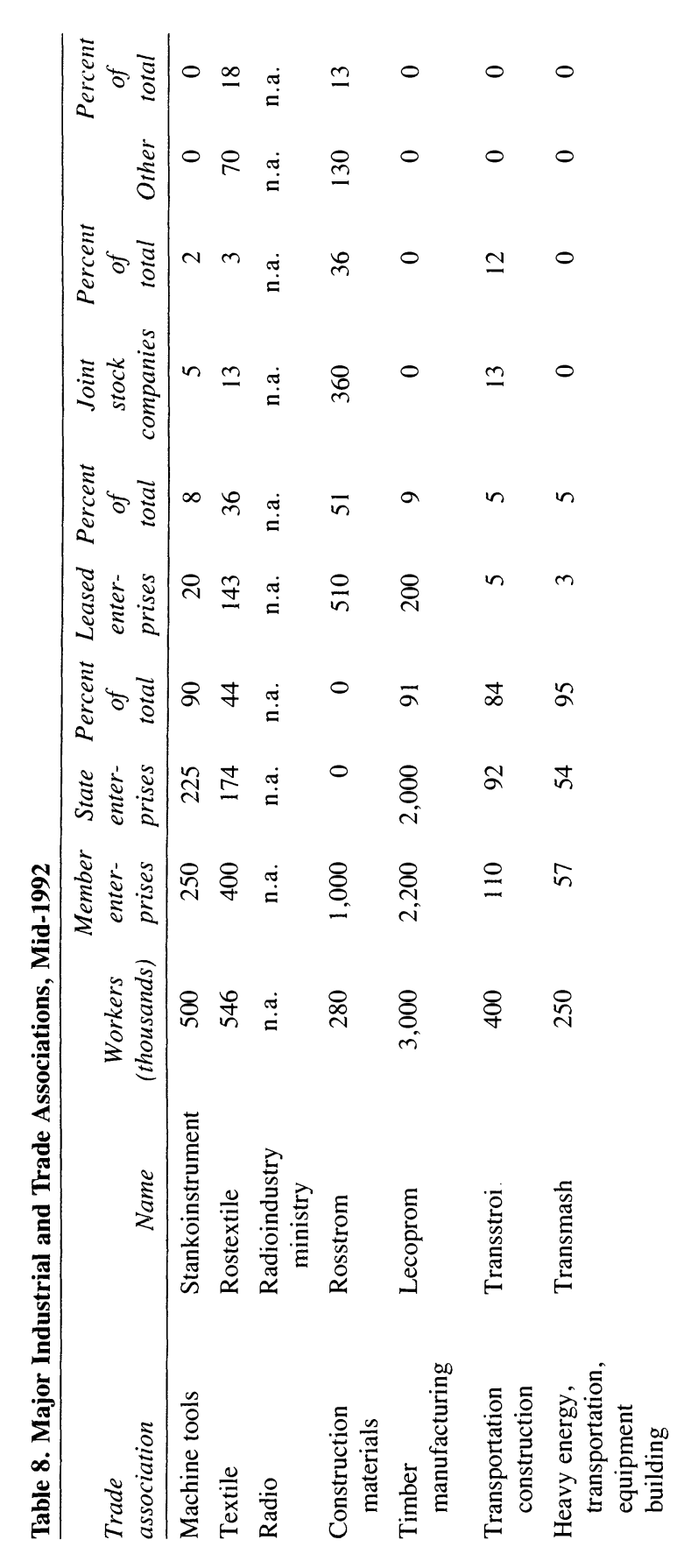




\begin{tabular}{|c|c|c|c|c|}
\hline 0 & 00 & 0 & $0-$ & $m$ \\
\hline$m$ & 00 & 0 & $0-$ & 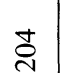 \\
\hline 0 & $q^{\circ}$ & 0 & $0-$ & $\varrho$ \\
\hline N & $\underset{q^{\circ}}{\circ}$ & 0 & $0-$ & 落 \\
\hline 0 & $q^{\circ}$ & 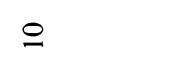 & ma & $\stackrel{\infty}{-}$ \\
\hline in & $9^{\circ}$ & $\stackrel{\infty}{n}$ & $-\subseteq$ & $\cong$ \\
\hline 2 & 요 & $\varnothing$ & $\stackrel{\circ}{\infty}$ & 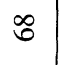 \\
\hline$\stackrel{8}{=}$ & ㅇ ㅇ & $\stackrel{\infty}{\sim}$ & ले & $\begin{array}{l}\stackrel{\mathcal{q}}{\Im} \\
\dot{\forall}\end{array}$ \\
\hline 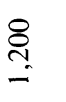 & \& & 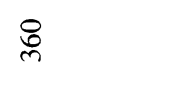 & $q \cong$ & $\begin{array}{l}\hat{\sigma} \\
\dot{q} \\
0 \\
0\end{array}$ \\
\hline 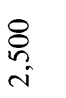 & $\gtreqless \&$ & \& & 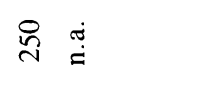 & $\begin{array}{l}\text {. } \\
\text { } \\
\sigma^{2}\end{array}$ \\
\hline 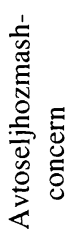 & 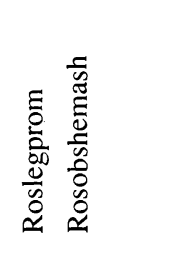 & 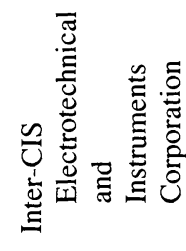 & 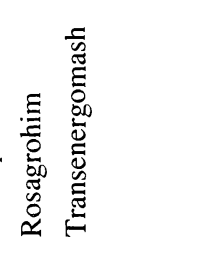 & \\
\hline 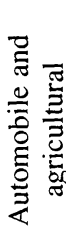 & 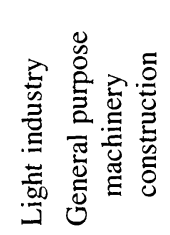 & 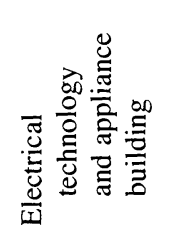 & 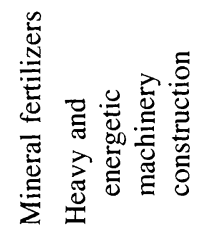 & 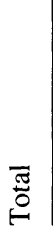 \\
\hline
\end{tabular}


ization program in 1992, this chaotic process of spontaneous privatization would likely have accelerated.

Trade associations were organized either as voluntary associations or as joint stock companies; legislation enacted in 1990 facilitated transformation of branch ministries into joint stock companies owned by the enterprises in the industry. Although interviews suggested considerable variation across associations, the main functions they performed were lobbying for state subsidies with the government and central bank, coordinating input supplies and production, providing investment and financial assistance, marketing, and research and development. Some associations offered a menu of services, and members could purchase only the services they wanted.

The associations appear to have played a very important support role for their enterprises in the 1990-91 period. By the summer of 1992, however, it was clear to many of the associations that the need for some of the functions they provided would decline as their member enterprises learned how to operate independently and other supporting institutional arrangements emerged. Most of the associations were active in lobbying for subsidies and special preferences and provided R\&D support well into 1992. Some of them successfully developed marketing and financial services. Although the associations continued to help coordinate input supply and distribution, their role here became less important as control over resources became dispersed. Still, the associations had valuable long-term relationships with key managers and state bureaucrats, and they were usually staffed with the best people from the corresponding branch ministries.

\section{The Emergence of Russian Privatization and Competition Policy}

Whether the Soviet leadership ever came to accept that merely weakening central control over the economy could lead to widespread spontaneous privatization and cartelization is unknown. By 1990 there was high-level Soviet interest in the general features of a more systematic privatization policy, but little thought appears to have been given to implementation. Privatization of industrial enterprises was not a high priority for near-term action in the so-called Shatalin Plan, the more 
aggressive of the two economic reform programs widely discussed in September $1990 .{ }^{48}$ During a visit to Washington in early October 1990 by Academician Stanislav Shatalin, the plan's primary author, it became clear to U.S. officials (including one of the authors of this paper) that very little thought had been given to exactly how the Soviet economy might be privatized. Shortly thereafter, Soviet President Gorbachev opted for a less aggressive approach.

More attention seems to have been paid to antimonopoly policy in this period. This may reflect the pace of spontaneous privatization, the perceived ubiquity of monopoly in the Soviet economy, and the widely accepted proposition that unregulated monopolies produce inflationinducing shortages. ${ }^{49}$ At any rate, in June 1990, four months before Shatalin's visit to the U.S., officials of the Soviet embassy asked the Antitrust Division of the U.S. Department of Justice and the U.S. Federal Trade Commission for comments on a detailed draft antimonopoly statute ${ }^{50}$ From this draft, after a good deal of consultation with foreign experts (mainly under the aegis of the Organization for Economic Co-operation and Development), the current Russian antitrust law was subsequently derived.

The Russian antitrust law was adopted by the parliament in March 1991 and became effective on May 1, 1991. The law providing the legal foundation for the current Russian privatization program was adopted in July 1991. Little beyond legislation seems to have happened on these fronts, however, until after the coup attempt of August 1991, which signaled the end of the Soviet Union. A new Russian government committed to radical economic reform was appointed by President Boris N. Yeltsin in November, and the Soviet Union was formally dissolved the next month.

A central reality, which affected these policies and much else, is that the Russian parliament elected before the coup attempt remained in office until its dissolution by force in October 1993 and generally opposed reform. The ideological makeup of the government varied as forces for and against reform struggled for control. The political envi-

48. See Rose Brady and Peter Galuska, "500 Days,' Business Week, October 1, 1990, pp. 138-48.

49. On this proposition see, for instance, Tsapelik and Yasin (1990).

50. Telephone interview with Russell W. Pittman, Chief, Competition Policy Section, Antitrust Division, U.S. Department of Justice, October 7, 1993. 
ronment within which privatization has been implemented has generally been hostile to reform, however, and that hostility has increased since the parliamentary elections of December 1993. In such an environment, rapid depoliticization of industrial activity is necessary for Russia to make the transition to a competitive market economy.

\section{Privatization}

The Russian privatization program was spelled out in a series of government decrees beginning in December 1991 and in a resolution of the Russian Supreme Soviet adopted in June 1992. This program and some of its effects are discussed in detail in Boycko, Shleifer, and Vishny, ${ }^{51}$ and we will only summarize it very briefly here. Because spontaneous privatization was proceeding rapidly in 1991, the government's program was at least as much an attempt to clarify ownership rights as it was a large-scale transfer of those rights.

Although an aggregation of enterprises may apply for privatization as a coherent unit and spontaneous privatization of subunits is accommodated, the Russian privatization program has operated under the general presumption that the existing legal entities-enterprises-were the appropriate economic units to become independent private firms. As far as we can tell, privatization was built around enterprises mainly for convenience and to move privatization along quickly. This decision did not result from any detailed functional or structural analysis of whether enterprises have the attributes of viable firms in a market economy. Those responsible for privatization recognized, however, that it is only the first step in an industrial restructuring process that will continue for many years after productive assets have been taken out of the hands of the government.

The privatization program has been administered at the level of the Russian Federation by GKI, the state property management agency, and at local and regional levels by its local and regional analogs; we refer to all these agencies as state property committees, or SPCs. As a first approximation, the privatization program divides all Russian enterprises into three categories.

The first category covers small enterprises (200 or fewer employees)

51. Boycko, Shleifer, and Vishny (1993). See also World Bank (1992, ch. 6) and Lainela and Sutela (1993). 
engaged in wholesale and retail trade, construction, agriculture, food, and trucking. These were given to local governments to sell for cash. In some cases ideology and the prospect of revenues have spurred rapid action at the local level, while other local governments have opposed reform and have done little. According to GKI, about 70 percent of small enterprises had been privatized by April 1994.

The second category consists of enterprises for which privatization poses special economic, political, or security problems. Enterprises in some sectors were not to be privatized at all under the 1992 program; others were to be privatized only according to special decrees of the government (making privatization very difficult during 1992 and most of 1993); and privatization of others required approval of detailed proposals by GKI after consultation with the relevant branch ministries. The Russian government is entitled to retain control of privatized enterprises falling into the last two groups (through GKI control of shares) for up to three years. Taken together, the sectors in these three groups account for a large fraction of economic activity, many provide important "infrastructure" services, and several have subsectors with natural monopoly characteristics that may imply public regulation or continued public ownership.

A decree issued in November 1992 prescribes a two-stage process for privatizing a list of "national interest"' industries drawn from all three groups in the second category. In the first stage, these enterprises are to be corporatized: converted to corporations with all equity owned by the government. After a three-year transitional period, full privatization would be considered on a case-by-case basis.

All remaining (large and medium-sized) enterprises have been placed in the third and most interesting category; they are slated for mass privatization. These enterprises are also to be corporatized initially. Divisions of enterprises can sometimes become independent firms during this process, and some attempts have been made to merge enterprises. After corporatization, workers and managers decide by vote between two options for the initial distribution of equity. ${ }^{52}$ The first option gives workers 25 percent of the shares for free, but these are nonvoting. Workers can buy another 10 percent of (voting) shares and

52. A third option is available but very rarely chosen; see Boycko, Shleifer, and Vishny (1993, p. 150). 
managers can buy 5 percent of voting shares for low prices. Some shares, but never more than 10 percent, may be set aside for workers and managers to purchase after privatization. Under the second option, workers and managers together get 51 percent of the shares at a low price. Up to 5 percent may be set aside for them to purchase after privatization.

After one of these options is selected and GKI or the local SPC (and, in many cases, the appropriate antimonopoly committee) approves the privatization plan, shares are sold to the public, usually at auction for vouchers. ${ }^{53}$ Vouchers, which are freely tradable, were distributed to the entire Russian population for a nominal cost between October 1992 and January 1993. About 20-30 percent of equity in privatized firms is typically sold to the public in voucher auctions, the first of which was held in December 1992. Disposition of the remaining shares has varied.

This privatization program has been the most successful component of Russian economic reform. By April 1994 private firms employed about 40 percent of Russian industrial workers, and voucher prices rose sevenfold between April and November 1993 in anticipation of the auction of some leading enterprises. ${ }^{54}$ But the structure of this program has two potentially important drawbacks.

First, the unusually generous benefits given to workers and managers to buy their support for the privatization program have translated into strong insider control of most newly privatized firms. ${ }^{55}$ Although some observers predicted otherwise, ${ }^{56}$ Boycko, Shleifer, and Vishny report that almost 80 percent of enterprises that made a choice by July 1993 chose the second option in order to retain control within the firm. They also present data from two surveys showing that for at least two samples of privatized firms, acquisitions after the public auctions had raised insider ownership shares to 60-70 percent on average.

Second, heavy reliance on voucher auctions has led to very dispersed

53. As Boycko, Shleifer, and Vishny (1993) discuss, bidders in each auction mainly just submit vouchers and get however many shares they buy at the equilibrium price, which is determined simply as the ratio of shares available to vouchers submitted.

54. Boyco, Shleifer, and Vishny (1993, p. 1) and "Russian Vouchers: Further to Rise," Economist, November 13, 1993, p. 90.

55. See Boycko, Shleifer, and Vishny (1993, p. 152-54). Workers also received substantial benefits, equal to 30 percent of the sales price, when local governments sold small-scale enterprises.

56. Lainela and Sutela (1993, p. 96). 
share ownership, so that privatized Russian firms generally lack large outside shareholders who can effectively oversee the actions of managers and workers. Boycko, Shleifer, and Vishny suggest that voucher funds, which issue their own shares in exchange for vouchers and invest them in voucher auctions, and individuals looking for opportunities profitably to change management control of enterprises exhibiting poor performance will eventually help to exert effective control over these enterprises. ${ }^{57}$ A presidential decree issued in late October 1993 strengthening the rights of outside shareholders may facilitate this process. ${ }^{58}$

\section{Antimonopoly and Antitrust Policy}

The 1991 Russian antimonopoly law, like the 1990 Hungarian and Polish laws and the 1991 law of the Czech and Slovak Federated Republic, more closely resembles the competition law of the European Community than that of the United States. ${ }^{59}$ The Russian law is concerned primarily with the abuse of dominant market positions, not with cartelization and exclusionary practices. Still, on its face the law provides a potentially adequate foundation for a sound antitrust policy. ${ }^{60}$

Article 3 creates the federal Committee on Antimonopoly Policy and Support of New Economic Structures (GKAP) and more than eighty regional counterparts as the enforcers of the statute; we refer to all these entities as antimonopoly committees, or AMCs. Private parties cannot sue for damages or relief. Because Russian universities have historically not taught either non-Marxist economics or any form of business or commercial law, the AMCs are necessarily short on relevant expertise-as is the entire judiciary. Some committees (particularly the GKAP and the St. Petersburg AMC) have received considerable technical assistance from Western experts, while others have received little or none. The AMCs do attempt to agree on policies and procedures, although the regional AMCs with which we have spoken seem somewhat more practical and market-oriented than the GKAP.

57. Boycko, Shleifer, and Vishny (1993).

58. See "Further to Rise."

59. Pittman (1992) provides a useful evaluation of key provisions of these laws.

60. Our discussion of this statute has been informed by a "Commentary" drafted by a joint Russian-OECD working group in late 1991 and early 1992. It appears, however, that neither the courts nor the enforcement agencies have felt bound by this document's interpretations of the statutory language. 
Given the economic and budgetary conditions under which they were created, the AMCs are also short on resources. Until late 1993 the GKAP was located in a crumbling building far from the center of Moscow, and the regional AMCs are dependent on regional governments for office space, housing, telephone service, and other resources. A presidential decree of August 1992 limits GKAP to a staff of 350 and the regional AMCs to a total staff of 2,500.

Article 4 says that an "economic subject" (which need not be a private firm) is dominant if it has the ability to exert "decisive influence on competition," to restrict other economic subjects' "access to the market," or otherwise to limit "the freedom of their economic activities." It also establishes a rebuttable presumption of dominance for subjects with market shares above a critical level that GKAP is to establish annually and that may not be less than 35 percent. ${ }^{61}$ In fact, GKAP has never established such a critical level, and Russian courts have required that the AMCs prove the existence of monopoly power before they will find dominance.

The law provides no operational guidance on how product or geographic markets are to be defined, although our impression is that the AMCs generally rely on administrative boundaries to define markets (cities, regions, or the entire country). In an attempt to clarify matters, the Russian parliament passed a resolution in August 1993 declaring that geographic markets were to be defined by "the economic ability of the buyer to acquire the commodity" within the market, and the absence of such possibility outside the market. Although the precise meaning of this language is unclear, most observers feel that its intent and likely effect will be to produce overly narrow (often subregional) markets in cases like shoes, for which consumers do not travel far to shop, but which retailers routinely buy from distant manufacturers. This resolution and the basic statute do not seem to contemplate the possibility of a market larger than the Russian Federation.

Article 5 provides a general standard for abuse and a nonexhaustive list of practices that are to be deemed abusive. These practices seem under some circumstances to include refusal to deal, tying, exclusive

61. Pittman (1992) reports that similar share thresholds are present (although with slightly different critical values) in the antitrust laws of other nations in the region. It is unclear how or why this happened, although we are told that the Polish law was the main model used by drafters of the Russian statute. 
dealing, price discrimination, a variety of vertical restraints, and "creation of obstacles to access to the market." There is clearly enough authority to prosecute real abuses, including those that would be "monopolization' ' under U.S. law. Unfortunately, this provision also seems on its face to justify a wide range of anticompetitive enforcement actions: abusive actions are defined in general as those causing "a material limitation on competition and/or encroachment upon the interests of other economic subjects or citizens." It is unclear when, if ever, innocent competition by a strong competitor will be found to "encroach upon the interests" of weaker firms.

Article 6 outlaws agreements among competing agents that in the aggregate occupy a dominant position if those agreements "have or might have as their result a material limitation of competition." This is not a strong provision. Because dominance must be proven, this provision does not provide a per se rule against naked cartel behavior. In addition, the Russian courts have generally required the AMCs to produce a formal, written agreement in order to move forward under article 6. Finally, an efficiencies defense is available in all cases, even those involving naked price-fixing, and an increase in competitiveness in foreign markets is proof of efficiency.

Article 6 also deals with agreements between buyers and sellers and does so in a more satisfactory fashion. Such agreements are always lawful if neither buyer nor seller occupies a dominant position. If there is dominance, the "material limitation of competition" standard used for horizontal agreements applies to vertical agreements as well. On its face, this is not only sound, it is a considerable improvement on current U.S. law.

Articles 17 and 18 give the antimonopoly authorities jurisdiction over the creation of new private entities by privatization and by merger. In both cases, advance notification is required for large transactions, and the agency has thirty days to reach a decision. ${ }^{62}$ The substantive standards seem basically sensible: consent is to be denied if the transaction could create a dominant firm or lead to "a material limitation of competition,' unless efficiencies (defined as in article 6) outweigh these effects.

62. Detailed procedures for coordinated evaluation of privatization proposals by the privatization and antimonopoly authorities were established by a joint memorandum at the level of deputy chairman in August 1992. 
Article 10 charges the AMCs with protecting consumers from false and misleading advertising, like the U.S. Federal Trade Commission, and with enforcing rights to trademarks and trade secrets. Articles 7 and 8 prohibit anticompetitive actions by government agencies. These are potentially very valuable provisions, ${ }^{63}$ but political realities and resource constraints seem to have prevented the antimonopoly authorities from effectively countering the anticompetitive tendencies of some government agencies (including, importantly, the Moscow city council) and some politically powerful state-owned enterprises.

Since 1991 Russian law has provided for criminal penalties of up to two years in prison for antimonopoly violations, but these sanctions have apparently never been invoked. The GKAP (but not the regional AMCs) can levy fines and force payment of damages. Unfortunately, the maximum fines specified in the statute have been rendered relatively unimportant by inflation. Article 19 allows the AMCs to dissolve firms found to have abused a dominant position, and article 22 appears to provide the authority for at least the other sorts of relief encountered in U.S. antitrust practice.

\section{Price and Product Regulation}

Until early 1992 all prices in Russia were, in principle, controlled by the State Committee on Prices (Goskomtsen). In practice, Goskomtsen developed norms for setting prices and reviewed enterprise pricing proposals based on those norms and other considerations related to general planning targets. Prices played more of an accounting role than an allocational role in the central planning process, although they did affect bonuses and the availability of cash for some activities. ${ }^{64}$ Wholesale prices were set by applying a "profit margin', to the sum of labor cost, materials cost, and a depreciation allowance. With time these margins came to reflect differences in capital intensity and political decisions regarding where production should be expanded or contracted. At the retail level, margins were applied to the wholesale price of each product.

63. Indeed, some Russian lawyers who participated in drafting the antimonopoly law considered these articles to be potentially its most important provisions. Personal interview with Nina Klein and Gainan Avilov, Institute of Legislation and Comparative Law, Moscow, February 1994.

64. Spulber (1991, pp. 44-48) provides an informative discussion. 
In November 1991 the new Russian government announced its intention to decontrol prices early in 1992. In the ensuing debate, some argued that, without continued comprehensive price regulation, Russia's many monopolists would reduce output, create shortages, and produce rapid inflation. In reaction to these concerns, Prime Minister Gaidar instructed the AMCs to compile lists of the monopolies under their jurisdictions. A monopoly was defined as an enterprise with a share of 35 percent or more of the sales in some market. Thus, an AMC-defined market could contain two "dominant" firms and a third on the threshold of dominance. Moreover, the AMCs have tended to define "markets" narrowly. Thus in July 1993, five bread factories in Yaroslavl, a city of about 600,000 people, were officially monopolies.

The Supreme Soviet endorsed this 'monopoly register', system in January 1992, and the antimonopoly committees began compiling lists. At the same time, many prices were in fact decontrolled, and, as most observers had predicted, prices increased rapidly. ${ }^{65}$ Retail prices rose fivefold in the first three months of 1992. Moreover, the rapid inflation that had exploded in 1991 (142 percent at the retail level) resumed after this initial price spike. Most outside observers blamed the continued rapid expansion of the money supply, undertaken both to finance huge government deficits (the Russian deficit was 31 percent of GDP at the end of $1991^{66}$ ) in the absence of an effective tax system and to provide continued subsidies to favored enterprises. At least some Russian officials were not so sure, ${ }^{67}$ however, and attention turned to the use of price regulation to check an inflation attributed in part to the abuse of monopoly power.

In August 1992 Prime Minister Gaidar authorized the federal and regional price committees to regulate the prices of most goods produced by firms on the monopoly registers. (The decree provided exceptions for "incremental output," new products, and cost reductions.) Although the decree did not specify a methodology for setting prices (or for implementing the exceptions), it did provide a list of "backstop"

65. World Bank (1992, ch. 1) describes these changes and their aftermath.

66. World Bank (1992, p. 7).

67. In early October 1992 a high official of the Price Committee explained to us at length how Russian inflation was cost-push, caused by the propagation of price increases for labor and raw materials and compounded by shortages of various sorts. When we inquired whether the rapid growth in the money supply might be contributing to inflation, we were told, "No, the money supply is not the problem: there is no shortage of rubles." 
margin ceilings that were to be applied in the absence of other special regulations. Enterprises caught violating the controls were to give up their excess profits. They were also subject to fines, but these began low and were made negligible by inflation. Authority to regulate prices under the monopoly register system expired at the end of 1993.

Other federal, regional, and local authorities continue to regulate prices, however. Table 9 provides information on the extent and nature of these price controls as of mid-1993. The legal basis for some of this regulation is unclear. As a general matter, price controls seem to be applied primarily to energy, various " public utility"' services, various foods (and vodka), and services viewed as basic necessities. In addition, at the time of privatization some local governments also imposed profile restrictions, which require retailers to carry certain products, particularly bread and milk. A presidential decree limits these restrictions to a maximum of three years, although some enterprises are apparently saddled with longer-lived restrictions. We consider the economic effects of all this regulation below.

\section{Competition Policy during the Transition}

The structure given the Russian economy by privatization can be expected to have long-lived effects on competition and economic efficiency. Private monopolies created in haste may endure for many years, and the failure of large numbers of nonviable private firms may have intolerable social and political costs. Yet, slowing the transition to a market economy in a political environment hostile to reform, to reduce the incidence of bankruptcy or monopoly or for any other reason, would risk reversal of the reform process. This tradeoff between depoliticization and careful demonopolization shaped several important aspects of competition policy during the transition.

\section{Restructuring Enterprises for Efficiency}

Just as the planned economy of the FSU lacked markets, it lacked entities that corresponded closely to firms in mature market economies. Enterprises, production associations, industrial associations, branch ministries, and the relationships among them were created by fiat rather 
Table 9. Russian Nonregister Price Controls, Mid-1993

\begin{tabular}{|c|c|}
\hline Good or service covered & Type of control \\
\hline Coal & Wholesale price ceilings and federal budget subsidies. \\
\hline Crude oil & $\begin{array}{l}50 \text { percent limit on margin when price exceeds } 4000 \\
\text { rubles a ton. }\end{array}$ \\
\hline Natural gas & $\begin{array}{l}\text { Wholesale price ceiling at } 3,600 \text { rubles per thousand } \\
\text { cubic feet. }\end{array}$ \\
\hline $\begin{array}{l}\text { Industrial electric and } \\
\text { district heat energy }\end{array}$ & Prices set by federal and regional bodies. \\
\hline Residential electric & $\begin{array}{l}\text { Uniform national price ceilings set by federal } \\
\text { government. Was } 1.5 \text { times } 9 / 1 / 92 \text { levels, on Sept. 1, } \\
\text { 1992, until August } 1993 \text { when it was increased by a } \\
\text { factor of } 15 \text {. }\end{array}$ \\
\hline \multicolumn{2}{|l|}{ Freight transportation } \\
\hline Railroad & $\begin{array}{l}\text { Maximum allowed price growth rate } \\
\text { (from Jan. 1, 1993). }\end{array}$ \\
\hline Sea transport & $\begin{array}{l}\text { Maximum allowed price growth rate } \\
\quad \text { (from Feb. 20, 1993). }\end{array}$ \\
\hline Air transport & 35 percent margin limit. \\
\hline River transport & 35 percent margin limit. \\
\hline Trucking & $\begin{array}{l}35 \text { percent margin limit (this may apply only to intercity } \\
\text { trucking). }\end{array}$ \\
\hline Communications services & $\begin{array}{l}\text { Regulated for firms on the monopoly register based on } \\
50 \text { percent limit on margins ( } 50 \% \text { margin). (Cellular } \\
\text { and satellite services appear exempt from price } \\
\text { controls.) }\end{array}$ \\
\hline Bread & $\begin{array}{l}\text { Wholesale price ceilings for grain, margin limits at } \\
\text { wholesale and retail ( } 15 \text { percent), federal budget } \\
\text { subsidies for grain. }\end{array}$ \\
\hline Baby food & Prices fixed at 1992 levels. \\
\hline Salt & $\begin{array}{l}\text { Maximum growth rate of prices (from Dec. } 31,1991 \text { ). } \\
\text { Regional bodies can abolish maximum price controls } \\
\text { or provide subsidies. }\end{array}$ \\
\hline $\begin{array}{l}\text { Milk, yogurt, cheese, } \\
\text { vegetable oil, vodka, } \\
\text { matches }\end{array}$ & $\begin{array}{l}\text { Maximum growth rate of prices (from Dec. 31, 1991). } \\
\text { Regional bodies can abolish maximum price controls } \\
\text { or provide subsidies. Price controls were still in effect } \\
\text { in major cities in August } 1993 \text {. }\end{array}$ \\
\hline Medicine & $\begin{array}{l}\text { Margin ceilings on wholesale and retail prices. } \\
\text { Wholesale margin is } 30 \text { percent. }\end{array}$ \\
\hline Gasoline and diesel fuel & $\begin{array}{l}\text { Regulated input prices and retail margins (and long } \\
\text { lines). }\end{array}$ \\
\hline Fuel oil & Price ceilings at 1.5 times prices before Sept. 10,1992 . \\
\hline Apartment rents & Regional councils can set price ceilings. \\
\hline \multicolumn{2}{|l|}{ Passenger transport } \\
\hline Railroad & Fixed tariffs (federal subsidies). \\
\hline Air & 20 percent limit on retail margins. \\
\hline Motor (bus) & Regulated by regional bodies. \\
\hline Postal services & $\begin{array}{l}\text { Ministry of Communications and Russian Price } \\
\text { Committee fix the prices for postcards, letters, } \\
\text { parcels, money orders, telegrams. }\end{array}$ \\
\hline Telephone & $\begin{array}{l}\text { Hookup and monthly fees in urban and rural areas are } \\
\text { subject to approval by the regional administration. }\end{array}$ \\
\hline
\end{tabular}

Sources: Various interviews and written sources. The status of price regulations is constantly in flux, and the legal basis for some local price regulations is obscure. 
than by the evolutionary process of natural selection in the marketplace. Many of the managerial functions performed by firms in market economies were performed by the branch ministries, not the enterprises.

The activities of individual enterprises were often closely linked with other enterprises within the same production or industrial association or simply controlled by the same branch ministry. An enterprise might thus depend heavily on other enterprises for services that a firm in a market economy would ordinarily provide for itself. Conversely, as a consequence of branch ministries' autarky policies, enterprises might produce goods and services that a firm in a market economy would ordinarily purchase from third parties. And because of the peculiarities of central planning and ideological influences, important functions such as marketing, advertising and the development of brand names, financing, and strategic planning may not exist at all.

Because the enterprises upon which the privatization process is built are, thus, unlikely to be efficiently structured firms for a market-driven environment, one argument for moving slowly on privatization in Russia was to take time to consider carefully what shape various privatized entities should take. Horizontal and vertical integration of legal entities or the division of legal entities could have been contemplated, along with other sorts of internal changes, to enhance the viability of the newly privatized firms.

There are at least three good reasons why this approach would have been undesirable. First, given our limited knowledge about how to design efficient organizations from outside and the likelihood that the structure of the Russian economy will change dramatically in the future, it would have been impossible to determine with any precision what an " efficient' Russian firm should look like. Any serious attempt to finetune the structure of thousands of privatized firms would have consumed huge quantities of economic and managerial expertise relative to the available supply. Second, the Russian bureaucracy was unlikely to be particularly able or willing to transform state-owned enterprises into viable private firms. The branch ministries historically resisted reform; their successor institutions have similar attitudes and no real knowledge of market economics or business management. Third, throughout the post-Soviet period there has been an overriding political need to proceed quickly with privatization so that the reactionary forces within the Russian government and enterprise structure cannot reexert control and stop 
reform entirely. Moreover, the pace of nomenklatura privatization at the start of this period meant that, if the official, legal process had not moved rapidly, little might have been left to privatize.

\section{Restructuring Enterprises for Competition}

Since at least the Gorbachev era, many thoughtful Russians have worried about creating a market economy dominated by entrenched monopolies. It has been argued that systematic deconcentration should be undertaken before full privatization, even though this might prolong privatization considerably. ${ }^{68}$ Although some have no doubt adopted this argument only as a useful tool to oppose reform in general, a good theoretical case can be made for deconcentrating before privatizing. ${ }^{69}$ Nonetheless, we believe that shifting the design of the Russian privatization program in this direction would have reduced overall economic efficiency. In part this belief reflects our view that the postprivatization monopoly problem need not be as bad as many have argued if appropriate policies to support competition are followed. We provide support for this view in the next section.

Moreover, a systematic procompetitive restructuring program would have encountered very serious versions of the problems discussed just above. In the United States, breaking up an existing firm through an antitrust case has typically taken many years. A forced dissolution that is appealed to the courts could take longer in Russia. ${ }^{70}$ Moreover, a program of this sort would represent a large-scale attempt to reassert

68. One might have expected to hear this from GKAP, but, because it long had less faith in competition than in monopoly register regulation, GKAP seldom if ever objected to a privatization plan on grounds of excessive concentration. Variants of this view, however, have been expressed by regional AMCs, which have sometimes argued for dissolution of potential dominant enterprises in advance of privatization; see Petrov (1993) for example. Some foreign observers have also argued for this strategy; see Coopers and Lybrand (1993, pp. 13-15).

69. See, in particular, Tirole (1991).

70. Coopers and Lybrand (1993) argue that AMCs need about six months to pass yes-no judgments on individual privatization plans. Obtaining, verifying, and analyzing the information necessary to formulate a workable dissolution plan would surely take considerably longer, especially because the antimonopoly authorities have little business and economic expertise and a more serious information disadvantage than do the U.S. authorities. Moreover, the consideration of any subsequent dissolution order appealed to the Russian courts could then take as long as a U.S. antitrust case under section 2 of the Sherman Act. 
government control at the expense of workers and managers, and it would surely encounter extralegal resistance on this score alone. Under the political conditions that have prevailed in post-Soviet Russia, creating a complex structure to deconcentrate industry could have derailed the reform process; it has been important to get enough of the economy out of the hands of the state to create an effective constituency for continued reform.

Moreover, the Russian privatization process has more or less automatically produced significant deconcentration in two ways. First, by focusing primarily on privatizing individual enterprises, and resisting creation of aggregations of enterprises built around existing production, industrial, and trade associations, the process has increased the number of private firms. Although the enterprise may have been the natural focus for privatization from legal and administrative points of view, our earlier analysis of the evolution of Russian industrial organization indicates that privatizing enterprises had the effect of splitting an unknown number of entities that corresponded more closely than their constituent enterprises to firms in developed market economies.

Russian industry was also deconcentrated through privatization of subunits, or "'breakaway divisions,", of enterprises. Under the privatization law, the workers' collective of a subunit or division of an existing enterprise can propose that the subunit or division be privatized by itself, as an independent joint stock company. Subunits with little capital do not require any approval from the original enterprise to privatize independently. Otherwise, approval from the original entity's workers' collective or a special decision of the relevant SPC is required.

The reservation of some equity for top management under both privatization options provided an incentive for such secessions, but it also provided an incentive for incumbent top management to oppose breakaways. Because its equity would be valuable only if the breakaway venture survived, division-level management has no economic incentive to spin off nonviable operations. At the same time, the managers of the original enterprise can always be expected to argue that the breakaway threatens the viability of what remained and to point to real and imaginary monopoly and holdup problems.

Voluntary separations that are primarily horizontal or conglomerate are unlikely to pose either sort of problem. Voluntary vertical separations are also likely to improve efficiency unless "asset specificity", 
between vertical segments is very significant or unless the vertical segment seeking to separate is a true natural monopoly in the long run. ${ }^{71}$ In the first case, if upstream and downstream markets are concentrated, allowing the vertical separation could facilitate entry at both levels and increase competition in the long run. In the second case, separation could be beneficial if the separating vertical segment were effectively regulated after privatization.

Separations could also reduce efficiency if the division seeking to separate is part of an integrated network, such as a long-distance telephone network, a railroad network, or a pipeline network. In such settings significant complementarities and network economies may be put at risk by dividing the network, but owners of some subsidiary entities may be able to gain a strategic advantage over the others by separating.

In November 1993 GKI and GKAP issued a joint regulation on the resolution of disputes between would-be breakaway units and their parent enterprises. This regulation generally encourages separations. Although most early discussions of the Russian privatization plan said little or nothing about the ability of subunits to secede from enterprises,${ }^{72}$ the secession provision has turned out to be of considerable importance. Of the 10,663 entities with privatization plans approved as of July 1, 1993, 1,237 (11.6 percent) were formed from subdivisions of state enterprises. ${ }^{73}$ Of course, the resulting deconcentration was probably not of commensurate importance in general, since many of these dissolutions were vertical or conglomerate in character and many of the "breakaway divisions", were tiny.

The voluntary separation process has been quite important in the cement industry, however. The number of Russian cement enterprises increased, through voluntary separations, from forty-two in 1990-91 to fifty-two at the end of 1992 and to sixty-five by October $1993 .{ }^{74} \mathrm{In}$

71. Andrei Petrov (1993, p. 20), first deputy chairman of the St. Petersburg AMC, argues that it may be undesirable to allow production units to separate from scientificproduction associations. We disagree. It is but a short step from this sort of thinking to government-imposed floors on $\mathrm{R} \& \mathrm{D}$ spending.

72. Compare World Bank (1992, ch. 6) and Lainela and Sutela (1993).

73. Boycko, Shleifer, and Vishny (1993, table 1).

74. The figure for 1990-91 is from the GKI data base discussed above. The others were provided by a Russian trade association of construction materials producers (Corporation Stroimaterialy) in November 1993. 
many cases privatized cement plants are producing more types of cement and have integrated into transportation. Anecdotal evidence suggests that finding a supplier for any kind of cement-nearly impossible at the start of the post-Soviet era-is now easy.

\section{Holding Company Proposals}

In response to the corporatization and privatization requirements associated with the mass privatization program announced in June 1992, most of the trade and industrial associations came to GKI with proposals for creating holding companies made up of their member enterprises. These proposals would have effectively transformed former branch ministries and their dependent associations and enterprises into single firms, thus creating widespread, entrenched, industry-level monopoly.

In addition, most of these proposals subverted the design of the privatization process and the emergence of a market for corporate control. By having the holding companies and subsidiary companies own substantial equity shares in each other, these proposals would reserve all equity for industry insiders: workers, managers, and former branch ministry officials. Holding company proposals were often accompanied by arguments that Russia should follow a "Japanese" or "Korean" model rather than a less integrated Anglo-Saxon design.

At first blush, these proposals seemed to be efforts by the former branch ministry officials to reassert control of their industries. But by mid-1992 these officials were not in a position to impose their will on the enterprises. Enterprise managers were not eager to give up their recently acquired autonomy to the bureaucrats whose thumbs they had been under for so many years. To go forward, holding company proposals had to offer benefits to the enterprise managers, and interviews with association officials confirmed that managers were the driving force behind these proposals.

Many managers were concerned that they and their enterprises would be unable to survive the uncertain and somewhat chaotic transition to a decentralized market economy. Some no doubt saw the holding companies as a way to re-create some of the familiar features of the old regime. Others saw these institutions as a life raft to cling to during the transition period, because they provided a source of expertise that responded to managers' concerns about survival in competitive markets. 
It would also be reasonable to expect that former branch ministry officials would be able to obtain subsidies from the central bank, which could be vital in the absence of workable capital markets. Although trade associations could provide these benefits, they could not deal with managers' uncertainty about their control over "their' enterprises. The holding companies, by eliminating outside shareholders, effectively gave managers much more control over their enterprises (at least collectively) than would have been the case if they had privatized separately and shareholding had become more widely dispersed.

In November 1992 the main principles of GKI's policy toward proposed holding companies were formulated in a regulation that acquired legal force when it was issued as an appendix to a presidential decree. Cross-ownership among subsidiaries in a holding company (or any other similar organizational structure) was banned outright. Subsidiaries were not allowed to own shares in one another or in the holding company itself. This produced some risk that the holding company might try to exercise its control rights in subsidiary firms and so made the holding company structure less appealing to those firms. Although privatizing independently also risked a loss of control, the likelihood that outside shareholdings would be dispersed made this risk tolerable in most cases. In addition, cross-ownership and complex ownership structures would tend to frighten outside investors, particularly foreign investors, whose capital was needed for capacity expansion and modernization.

GKI was also concerned that holding companies with large market shares might reduce competition but recognized that the creation of some holding companies would increase productive efficiency. GKI's time and resources, however, did not permit a detailed, in-depth review of the likely competitive and efficiency effects of all the holding company proposals it received. Moreover, the enterprises involved in a rejected proposal could always try to integrate or reintegrate after privatization through merger. GKI therefore decided to approve creation only of those holding companies that would not control more than 35 percent of a relevant market and that could make a reasonable case that the proposed structures would bring about substantial efficiency gains.

This strict holding company policy almost certainly deterred many anticompetitive proposals. A GKI experts' commission set up to review holding company proposals dealt with only about twenty of them between October 1992 and January 1993, and it approved several. One, 
for instance, joined five enterprises, located in different parts of the country, that transported very heavy equipment. These enterprises appeared to account for about 20 percent of the national market for such services, and their claim that efficiency would be increased by the ability to provide door-to-door service made good sense. On the other hand, the commission rejected an early proposal to join thirty-seven fertilizer-producing enterprises, all former members of a single industrial association. The resulting holding company would have had a very large share in several markets, and the only claimed efficiencies were for functions that could easily be performed by a Western-style trade association, which GKI encouraged the enterprises to form. In some cases, however, industries were able to bypass GKI and obtain decrees from the government for holding company structures that otherwise would have violated the regulation.

GKI's response to the early wave of holding company proposals did not preclude later attempts to re-create multienterprise structures. It left these integration decisions to the postprivatization industry restructuring process, when they must be evaluated under the Russian antimonopoly law. In this connection, however, it is worth noting that GKI and GKAP shared responsibility for reviewing privatization proposals, including holding company proposals. GKAP could have objected to these proposals and helped to write the regulation to govern them. As far as we can tell, however, GKAP did neither. Indeed, there is some indication that GKAP found the holding company proposals attractive on the traditional Soviet argument that reducing the number of firms would simplify price regulation. Obviously, this promonopoly mindset is inconsistent with GKAP's functioning as an effective procompetition agency.

\section{Governance and Financial-Industrial Groups}

The 1992 holding company proposals mainly involved agglomerations of enterprises in the same industry or previously subject to control by the same branch ministry. In the summer of 1993, a new set of proposals for "financial-industrial groups"' (FIGs) encompassing enterprises in different industries gained considerable support within the government and the parliament. ${ }^{75}$

75. A specific proposal by Mikhail Yuriev, deputy chairman of the Union of Industrialists and Entrepreneurs, attracted considerable attention. Much of what follows is 
The argument for FIGs usually begins with the sensible observation that an economy with many thousands of one-plant joint stock companies controlled by their workers and managers and without a real banking system, uniform accounting standards, or efficient securities markets is not likely to have either efficient private firms or an effective market for corporate control. Without FIGs, however, Russia must rely heavily on the market for corporate control to realign asset ownership and control in efficient directions and to replace poor managers with good ones.

Moreover, workers and managers who control their firms will have a strong preference (at least if they are even moderately myopic) to distribute profits to themselves in the form of wages and bonuses rather than to themselves and others in the form of dividends. Without efficient banks or workable financial markets, cash-poor firms may have great difficulty financing even attractive investments, and the necessary restructuring process may operate slowly.

FIG proponents argued that the only way to deal effectively with these problems was to force the creation of several large, geographically dispersed (for political reasons) conglomerate organizations, covering a quarter to a half of Russian industry and modeled vaguely after the financial-industrial groups of Japan or Korea. The basic plan was to merge "cash cows" with enterprises having attractive investment projects, to run an internal capital market within each FIG, and to rely on talented top management to ensure that constituent enterprises are competently run. Mechanically, corporatized enterprises slated for inclusion in a FIG would be held off the voucher auction market and a majority of their equity given to a holding company. A majority of the FIG holding company's shares would then be auctioned for vouchers. The rest would be held in trust for the FIG's top managers, to be given to them as a bonus if and only if they met legislatively fixed short-term performance targets and to be auctioned otherwise.

These proposals have several problems. First, the FIGs are likely to

based on several hours of discussion with him in August 1993. Mr. Yuriev managed, somehow, to acquire ownership of nine bulk chemical plants before the current privatization regime was put in place, and he seemed to be selling effectively both in Russia and abroad. His plants produced thirty-nine products that were on either federal or regional monopoly registers. He was very bullish on the near-term competitiveness of Russian industry. 
be inefficient. Multi-industry enterprises in market economies have worked well only when they have been built carefully; the conglomerates patched together quickly in the United States in the 1960s generally performed poorly. The proposed FIGs would be slapped together even more hastily than these unworkable aggregates, and Russia's underdeveloped transportation and communication systems would extract a high price for uneconomic geographic dispersion. Because the FIGs would be both inefficient and "too big to fail," they likely would need and receive substantial state subsidies soon after their formation, thus inhibiting depoliticization.

Formation of FIGs on a large scale would also slow privatization. Unless enterprises are to be selected by drawing names from a hat, in which case the level of inefficiency would be staggering, individual FIGS would take months (at least) to construct. Many, if not most, corporatized enterprises would have to be held off the voucher auction market, in some sort of public-private limbo, until the process is concluded. As we have argued repeatedly, delaying full privatization is very risky indeed.

Finally, schemes that promise large rewards to FIG managers who meet short-term performance standards have the potential to become large-scale, highly visible theft. That is particularly likely in the absence of well-defined accounting standards and efficient securities markets.

Using these and related arguments, proreform forces in the government managed to prevent the adoption of the initial FIG proposals. Nonetheless, the problems that FIGs were proposed to solve are real, and a weaker FIG proposal was adopted by presidential decree in December 1993. This decree puts the Russian government on record as in favor of FIGs in general, calls for the near-term formation by the government of at least two FIGs composed of state enterprises, and provides for debt writedowns for enterprises included in privately formed FIGs. FIGs must be "established in conformity with antimonopoly legislation of the Russian Federation,' but it is unclear whether GKAP has any general right of prior review. As of early 1994 some Russian observers feared that the government would move aggressively to form FIGs from enterprises that had not yet corporatized and that it would increase substantially the incentives for the voluntary formation 
of FIGs made up of private firms. ${ }^{76}$ Even if that does not happen, the December decree seems by itself to raise problems of inefficiency and of anticompetitive structure and behavior.

\section{Competition Policy in the Medium Term}

The development of efficient markets in Russia faces many serious challenges that seem likely to endure well beyond the completion of the current privatization process, including a parliament opposed to reform, irresponsible central bank credit policies likely to accelerate already rapid inflation, the absence of a workable commercial banking sector, impediments to import competition, the absence of workable private real estate markets, ${ }^{77}$ ill-defined property rights and problems with contract enforcement, a shortage of trained and able managers, and an ineffective bankruptcy law. ${ }^{78}$ Much has been written about these and related problems, and we will not attempt to add to that literature here. Instead, we focus on the traditional concerns of antitrust and competition authorities, as well as industrial organization economists.

\section{Russian Market Structures}

Given the current structure of Russian industry, the key question is which levels of institutional, geographic, and product aggregation are likely to provide the best indicators of postprivatization competitive conditions. A large fraction of Russian industrial production has taken place in production associations that may or may not have merged formally into a single legal entity before privatization. If these production associations are privatized as a unit, rather than as separate enterprises, or if they continue to coordinate their activities as separate

76. We have been told that smaller FIGs based on local industries have been formed in some remote provinces after the voucher auctions were conducted, through contributions of shares to a common fund.

77. In October 1993, President Yeltsin issued an important decree that allows trade in land and suggests procedures for establishing property rights and for buying out land by its current users, as well as procedures for land sales.

78. Significant reforms in the bankruptcy process were announced by the government in September 1993. 
enterprises, or if they merge after privatization, the actual level of seller concentration after privatization could be much higher than enterpriselevel statistics indicate. GKI has taken a hard line against this sort of consolidation and has sought to convert enterprises, not trade associations or other multienterprise structures, into private firms. If, however, the forces that led to the 1992 holding company proposals have not dissipated, as they apparently have not, there will surely be pressures to consolidate and coordinate horizontally after privatization. Nevertheless, unless the FIG decree of December 1993 presages a major promerger shift in Russian policy (a development that cannot be ruled out as this is written), we believe that, with adequate merger policy tools, the AMCs should be able to oppose anticompetitive consolidations effectively. Accordingly, concentration data at the enterprise level are likely to be more informative about Russian market structure in the medium term than are data at any other level of institutional aggregation.

Large Russian enterprises tend to be more concentrated geographically than their U.S. counterparts. Russian enterprises also tend to serve only relatively small geographic areas surrounding their factory complexes, with other enterprises producing similar products distributing their output in different geographic areas. If these geographic sales patterns were to persist, monopoly or oligopoly could be a much more important problem than either is in developed market economies with similar national-level concentration statistics. As we have stressed, much here depends on the evolution of the transportation and distribution systems. If the highway system is upgraded, the rail system improved, and wholesale and retail trade developed, and if regulatory policy does not blunt market forces, privatized enterprises will find it relatively easy to serve broader markets. If not, concentration will be higher than implied by national-level data. The development of a wide array of national markets in Russia is feasible, if only because of the great excess capacity in the rail system, but it is certainly not inevitable.

Similar considerations affect aggregation along the industry-product dimension. Soviet enterprises generally produced a narrower array of products than Western enterprises in the same industries. If transportation and distribution systems develop, Russian firms can be expected to produce similarly broad lines - the diversification in the cement industry is a case in point. If this sort of diversification becomes general, 
the four-digit level of aggregation often used by Western economists to analyze industrial market structure will be the most relevant for analyzing Russian industry as well, and concentration at this level is much lower in Russia than at the level of individual, narrowly defined products used in most previous discussions of Russian industrial structure. We believe that this diversification will surely occur, but we cannot predict how long it is likely to take.

Of course, diversification opportunities will vary widely among industries. A textile factory producing women's dresses can expand to produce a wide range of clothing more easily than an enterprise producing freight cars can shift to producing locomotives. Expanded production and sales by enterprises in the military-industrial complex are another source of competition, as are sales of products by vertically integrated enterprises that previously produced only for their own use. A few examples of postprivatization diversification provide grounds for at least guarded optimism.

A textile enterprise in Vladimir, an industrial city about 200 kilometers from Moscow, produced only women's dresses under central planning and sold only to retail establishments in its region. It was part of a regional industrial association that consisted of about ten other textile factories, each of which also produced a specialized line of clothing (such as children's clothes or men's shirts). After privatization and market liberalization, the textile enterprise expanded its production to a wide variety of clothing and now sells outside its region and abroad. Other enterprises once in the same regional industrial association have also tried to diversify the clothing that they produce, but with mixed success. Although they are separate enterprises, the former members of the association continue to cooperate and support one another, and they hope to create a more formal structural relationship (perhaps by merger) in the future.

A factory located outside Moscow employs 1,235 people to produce several types of large industrial fans. One of the first enterprises privatized in Russia during the Gorbachev era (through a managementworker buyout in 1989 financed with credits from customers), it merged with another fan factory in 1991. The firm faces competition from several other fan producers and, most recently, from enterprises that used to produce motors and have diversified into industrial fans. The fan factory has also diversified into the production of specialized heaters 
with fan-driven air circulation. It is the only Russian producer of heaters of this type. There is potential import competition, but the relative cost of imports is very high.

Moscow Bread Factory \#10, one of the largest wholesale bread bakeries in Moscow, produced only brown bread of a particular type under the old regime. The bread was transported to retail outlets within a particular geographic area designated by a department of the Moscow city government according to a central transportation and delivery plan using trucks owned by a local trucking enterprise. ${ }^{79}$ Since privatization the bakery has diversified to produce white bread, pastries, and, when the key ingredient can be obtained from Ukraine, a special rye bread that it exports to New York. It has also purchased its own delivery trucks and is attempting to open its own retail outlets. It has negotiated arrangements with an agricultural cooperative that will enable it to sell dairy products and eggs in its retail shops. These efforts have been impeded by the Moscow city government and by a trade association that derives from the former department in charge of bread in the Moscow city government.

A final example: each of Russia's ten major tire producers used to produce only one or two specific types of tires. During the last two years, all of them have diversified and now produce several types of both truck and auto tires. At least one manufacturer is actively searching for retail outlets because it is no longer the sole supplier for a major automobile factory. As one might expect, buying tires of any type is much easier than it was two or three years ago.

We believe that these sorts of diversification of existing manufacturing enterprises (including those in the military-industrial complex) into related product lines and new geographic areas are likely to be the most significant source of increased competition at the product level in the medium term. The speed and extent of such diversification will depend not only on how the Russian antimonopoly law is applied, but also on policies affecting transportation, communications, wholesale and retail trade, and commercial and industrial real estate markets. With sound policies, monopoly need not be as pervasive in Russia after privatization as many observers have suggested. ${ }^{80}$

79. See Coopers and Lybrand (1993, vol. 2) on the bread industry in St. Petersburg.

80. In particular, the situation is not as bleak as suggested by Boycko, Shleifer, and Vishny (1993, pp. 162-65). 


\section{Price Controls}

Russians are very comfortable with price controls and have extensive experience with the application of accounting formulas to set prices. Under the old regime, however, these prices did not play an important allocational function and thus could be only loosely related to real economic costs. Moreover, inflation and changes in the structure of the economy are rapidly weakening relations between current costs and historical markups. The Russian system simply does not contain sufficient information and expertise to fix efficient prices in a wide range of industries. As a result, if the many regulatory constraints described above are binding over any period of time, very serious distortions could be produced: economic efficiency could easily be more threatened by pervasive regulation than by pervasive monopoly. It is thus very important to know whether price controls are likely to be binding now and in the future, although available evidence is necessarily largely anecdotal.

Consider the monopoly register system first. We have met twice with the leaders of the Russian Committee on Prices. Particularly during 1992, they were clearly unenthusiastic about price decontrol and eager to regulate as many prices as possible. In this same period, the GKAP leadership was similarly enamored of price controls under the monopoly register system. As of August 1993 nearly 7,000 enterprises had products listed on a monopoly register. Leaders of both GKAP and the Committee on Prices have been quick to point to numerous market imperfections to justify price controls but have seemed to lack any appreciation of the fact that price regulation can be very costly. ${ }^{81}$

Table 10 lists various two-, three-, and four-digit industries (using the U.S. SIC classification) along with the backstop margin ceilings implied by the 1992 regulations for products in these industries produced by enterprises on a monopoly register. Margins are expressed as a percentage of the sum of labor cost, materials cost, and a depreciation allowance; they are not gross margins. Table 10 also compares these margin ceilings with the actual wholesale margins realized for these industries in the United States in 1987. The U.S. margins are calculated in two ways. The first method assumes that the base production cost is

81. We have often been told, "No problem setting the right prices, we have been doing it for decades." 
Table 10. Wholesale Margin Regulations for Enterprises on the Monopoly Register (1992-93), compared with Realized Margins in the United States

Percent

\begin{tabular}{llccc}
\hline $\begin{array}{l}\text { SIC } \\
\text { code }\end{array}$ & \multicolumn{1}{c}{ Industry } & $\begin{array}{c}\text { Russian } \\
\text { margin } \\
\text { ceiling }\end{array}$ & $\begin{array}{c}\text { U.S. margin } \\
\text { (without } \\
\text { amortization) }\end{array}$ & $\begin{array}{c}\text { U.S. margin } \\
\text { (with capital } \\
\text { expenditures) }\end{array}$ \\
\hline 33 & Primary metals & 25 & 28 & 27 \\
34 & Fabricated metals & 25 & 37 & 36 \\
28 & Chemicals \& allied products & 25 & 71 & 67 \\
244 & Logging & 50 & 31 & 29 \\
205 & Baking products & 20 & 79 & 75 \\
2041 & Flour milling & 20 & 24 & 24 \\
207 & Fats \& oils & 25 & 19 & 18 \\
2062 & Cane sugar refining & 25 & 12 & 12 \\
201 & Meat products & 10 & 12 & 12 \\
202 & Dairy products & 10 & 24 & 23 \\
21 & Tobacco products & 40 & 160 & 151 \\
2098 & Macaroni \& spaghetti & 25 & 82 & 78 \\
27 & Publishing \& printing & 25 & 71 & 67 \\
2834 & Pharmaceuticals & 30 & 156 & 140 \\
\hline
\end{tabular}

Sources: Russian margins are from Russian Federation Regulation 576, August 11, 1992, as translated by Ilya Segal. The U.S. data are computed from the 1987 Census of Manufactures. Summary, Vol. 1.

equal to the costs of labor and materials. This is a fair approximation of the current situation in Russia, since the rapid inflation of the last few years has made nominal depreciation charges negligible. The second margin calculation takes current capital expenditures as an expense. This saves the trouble of estimating depreciation for these industries and is certainly good enough for our purposes; it does not change the margin calculations very much.

Note first that the Russian margin ceilings vary much less from industry to industry than do the realized U.S. margins. Indeed, the Russian price control regulations apply the same margin ceilings to products in industries that have very different realized margins in the United States. Also, the U.S. margins are, on average, much higher than the Russian margins. The margins are closest to one another for the production of commodities where marketing, packaging, and distribution costs are likely to be low (such as flour milling, cane sugar refining, meat products-primarily meat packing-and fats and oils). They are farthest apart where marketing, advertising, distribution, and 
R\&D costs are important (for example, pharmaceuticals, chemicals, tobacco products, and publishing and printing).

Thousands of Russian enterprises were found to be monopolists of one or more products and were thus subject to this system of price controls, but everyone with whom we spoke outside the government said that these controls were easy to evade and were evaded as a matter of course. Although legal authority for monopoly register regulation ended at the end of 1993, the current government has pledged to use regulation instead of monetary policy to control inflation, and the most natural way would be to bring back the monopoly register system. If this system were made effective, the cost of binding, uneconomic price regulation of much of Russian industry would be huge.

The nonregister price controls described in table 9 appear to be more immediately troublesome. Energy prices are clearly being held below equivalent world market levels. Coal is still heavily subsidized. In August 1993 residential electricity prices were raised by a factor of fifteen-to about one-tenth of the comparable price in Western Europe and the United States. Although gasoline prices were increased during late 1992 and 1993 from a few pennies per gallon to levels nearly equivalent to those in Western Europe, lines are still long at filling stations throughout Moscow, a secondary market is active, and roadside vendors sell from small containers.

The Russian economy is one of the most energy intensive in the world,$^{82}$ and controls keeping energy prices far below efficient levels are potentially very costly. (As one might expect, of course, significant quantities of petroleum products have been leaking out of the system and are being sold illegally outside of normal channels.) These policies have also given certain energy-intensive Russian industries (notably aluminum and bulk chemicals) unsustainable competitive advantages in world markets.

The retail price controls on food (particularly milk and bread) also appear to be binding, in some cases leading to distortions in quantity and quality. ${ }^{83}$ Indeed, the combination of subsidies for wheat used to bake bread and price controls on bread has led bakeries to ship quantities

82. See, for instance, World Bank (1992, p. 176).

83. BCG (1993). 
Table 11. Selected Responses to Small-Scale Privatization Survey, 1993

Small privatized firms reporting

Percentage

Restrictions on markups reporting

Binding restrictions on markups

84.7

Profile restrictions

74.4

Binding profile restrictions

96.2

Employment restrictions

14.2

Binding employment restrictions

67.8

A major problem with the rackets

13.0

A major problem with transportation

15.7

20.2

Source: GKI Small-Scale Privatization Survey. Note that profile restrictions require that certain products be offered for sale.

of bread to farms to be used as animal feed. In return, the bakeries get milk, eggs, and other dairy products, which are also price controlled. In August 1993 a major crisis emerged in retail bread distribution when retail shop owners announced that they would stop carrying bread if the prices were not raised. We have been told that price controls on baby food have made it difficult to find domestic baby food, although imported baby food is available at high prices.

A survey conducted for GKI in mid-1993 and summarized in table 11 confirms that retail price controls are binding. ${ }^{84}$ About 85 percent of those responding were subject to price controls, and 74 percent of shops responded that these controls were binding. Interestingly, profile restrictions imposed during privatization are generally not binding,${ }^{85}$ and employment restrictions appear less problematic than one might have thought. Table 11 also suggests that organized crime ("rackets") may be less of a problem in Russia as a whole than Moscow-based Western journalists suggest. In addition, the apparent lack of widespread transportation problems is consistent with other evidence that local trucking markets are beginning to work relatively well in most areas.

84. The survey was conducted in May-July 1993 and covered 452 businesses, divided among seven cities in different parts of Russia as follows: Voronezh, 43; Krasnodar, 49; Moscow, 47; Nizhny Novgorod, 61; Omsk, 102; Smolensk, 80; Yaroslavl, 70. Privatized businesses were selected randomly in each city from three groups, privatized through different procedures: sold at auction ( 25 percent of the sample), sold at commercial tender ( 40 percent), and bought by workers' collective ( 35 percent).

85. As noted above, profile restrictions are requirements, attached to the privatization of a retail establishment, that certain products, often bread and milk, continue to be offered for sale for a specified period of time. 


\section{Problems of Antitrust Policy}

Our interviews indicate that the AMCs have devoted most of their effort to the currently defunct monopoly register system. Of the 1,067 court cases involving the antimonopoly law initiated in 1993, about 70 percent concerned disputes about whether an enterprise should be placed on the register. The AMCs also devote considerable effort to their consumer protection and privatization process responsibilities. Not much conventional antitrust enforcement is done. Only about 1 percent of court cases under the antimonopoly law have involved the anticartel provision of the law, for instance. The antimonopoly law has not been used to break up any enterprises.

The single most important change that can be made in Russian antitrust policy is to shift the focus of the AMCs definitively toward development and enforcement of mainstream antitrust policy. Recent signs in this regard, particularly at the regional level, ${ }^{86}$ have been encouraging, but the shift is not yet complete. The antitrust authorities must become convinced that price regulation is the wrong way to deal with monopolies or oligopolies that flow from innovation or historical accident rather than inevitably from technology (that is, natural monopolies). Their focus instead should be on specific behavior that suppresses competition directly (by cartelization or merger to monopoly) or indirectly (by impeding the entry or expansion of efficient competitors) and on law enforcement.

The AMCs should also interpret their statutory obligations to promote competition (rather than just to regulate or restrain monopolies) more broadly. As we have argued, the development of competitive markets in Russia depends on public policies governing telecommunications, transportation, energy, wholesale and retail trade, and real estate and financial markets. Major decisions about the structures and, in some cases, the regulation of these sectors are yet to be made. Some of them (notably telecommunications) have antiquated facilities that cannot support a modern market economy. Others (such as electric power and railroads) have reasonably good facilities and expertise, but

86. On the whole, for instance, Petrov (1993), a St. Petersburg official, exhibits a constructive mindset. In addition, the federal antimonopoly program adopted in November 1993 states clearly that the AMCs' purpose is not to regulate monopolies, but to promote competition and seek to decrease concentration levels. 
their capital stocks are deteriorating rapidly because of fund shortages, neglect, and organizational problems. The AMCs could play a more useful role here if they became advocates for policies that promote competition within these sectors and in the industrial sectors that depend on them.

In addition, some changes in the Russian antitrust law seem appropriate. As we have noted repeatedly, substantial postprivatization merger activity is likely to result from efforts to restructure enterprises and to replace managers. Russia clearly needs a sound merger policy, effectively applied, to prevent mergers that are likely to create significant competitive problems and to permit mergers that are likely, on balance, to enhance efficiency. The substantive standard in article 17 of the antimonopoly law, which bars mergers that could create a dominant firm or a material limitation of competition and provides an efficiencies defense, is basically sound. This general standard, however, provides little guidance either to firms contemplating merger or to frontline enforcement personnel in the AMCs. Indeed, it is not clear that a mechanism even exists to ensure that mergers are reported to the antimonopoly committees before they are consummated. The antitrust authorities will find it difficult to deal systematically with the likely wave of merger applications, let alone in a manner likely to enhance economic efficiency, without review authority and specific, public standards-perhaps along the lines of the U.S. Merger Guidelines. As this is written, GKAP is moving actively to develop merger guidelines. ${ }^{87}$

Merger policy as usually implemented will not deal with all approaches to integrating or reintegrating independent firms, however. We have heard of two devices that illustrate what the AMCs can expect. In the first the staff of a former branch ministry or production association establishes a "trade association" as a private firm, jointly owned by a group of privatized firms in the same market. The association does not have any financial interest in, let alone control of, the operating enterprises, but it is plainly intended to control their pricing and pro-

87. In addition, the requirement that the antimonopoly authorities approve or disapprove a merger application within thirty days is not workable, given the scarcity of expertise and of information on Russian industry under which the enforcement authorities must operate. There is nothing in the Russian law to delay a merger or acquisition until the agency has the necessary information to evaluate it. The introduction of the opportunity for a "second request"' and the associated time for collection and analysis of information as in U.S. antitrust law would probably be desirable. 
duction. In the second approach a parent holding company or bank owns relatively small shares (15 percent, say) of the stocks of several subsidiaries in the same market. It does not, very strictly speaking, control the subsidiaries, but, particularly in the absence of any large outside shareholders, it obviously will coordinate their activities.

GKAP has proposed to deal with these sorts of devices by amending the antimonopoly law to declare the firms involved to be a single entity if, despite the lack of formal control, the central enterprise "is in a position to control other businesses' activity by . . . exercising other means ultimately to influence their decision-making." We are concerned, however, that it may be difficult to prove that control " by other means" is possible in cases where control in the ordinary sense is absent. An alternative approach would be to establish a rebuttable presumption that firms linked, directly or indirectly, by ownership of nontrivial shares of equity (above 5 percent, say) have agreed to coordinate pricing and production. This inferred agreement would then be subject to the law's prohibition of agreements that might materially limit competition.

Trade associations that do not involve ownership links are yet another device that might be employed to achieve horizontal integration. Some of the holding company initiatives that GKI blocked during privatization have resulted in the creation of yet another set of trade associations. Indeed, as the example of the fertilizer industry indicated, GKI has encouraged creation of trade associations in some instances. There is nothing inherently undesirable about trade associations; they can provide many useful services that are consistent with promoting competition and enhancing market efficiency. In light of the long historical linkages and cooperative relationships among enterprises subject to the same branch ministry, however, and their potential mutual interest in impeding the emergence of competition, the activities of such associations should be carefully circumscribed so that they are not used to facilitate price fixing, especially through agreements allocating specific products or geographic markets among nominally competitive firms.

Unfortunately, Russian law does not contain a per se rule against cartel agreements, whether or not they are connected with trade associations. The requirement in article 6 that the antimonopoly authorities prove that the parties to an anticompetitive agreement collectively occupy a dominant position should not, in principle, hinder prosecution 
of price-fixing and related agreements with significant efficiency costs. If prosecution is impeded in practice because dominance is difficult to prove, the requirement should be removed. A more serious problem is that Russian courts have required prosecutors to produce a signed contract or similar document to prove that an agreement exists. If this requirement stands, it will clearly vitiate prosecution of price-fixing, market division, and related practices.

Finally, conversations with AMC officials often turn to instances of anticompetitive behavior by government officials, particularly at local and regional levels. We learned, for instance, that in the summer of 1993, the Moscow city government was sending the privatized Moscow champagne bottling enterprise detailed instructions on how much of its output should be shipped to which retailers. The Moscow government also withheld subsidized apartments and working capital grants from Bread Factory \#10 when it challenged restrictions of this same sort. Activities of this kind are perhaps explicable as natural reactions of those who have been taught since infancy that chaos reigns in the absence of government planning, but they constitute serious obstacles to the emergence of competitive markets in some sectors and regions. The AMCs have adequate statutory authority to deal with this problem, but GKAP seems to lack the will to act, and the regional AMCs plainly lack the political power to accomplish much in this sphere. In our view this serious problem is fundamentally political, and it awaits a political solution.

\section{National Interest and Natural Monopoly Industries}

The decree issued in November 1992 establishing a special framework to govern the privatization process for certain "national interest" industries covered communications, electric power, oil and gas production, precious metals and gemstones, uranium, military factories and national security institutions, rail and air transport, river and sea transport, R\&D and engineering enterprises, specialized construction, wholesale trade enterprises purchasing for the state, hard liquor (including vodka), and all enterprises with more than 20,000 employees. The decree embodies an implicit commitment to privatize these sectors, but it recognizes that their "special status" requires significant attention to the details of how they are privatized and restructured. To facilitate 
a smooth transition, the decree provides for a three-year period after corporatization during which privatization and sector restructuring will take place. In this period, the government, through GKI, can retain controlling blocks of shares (or special "golden shares" conveying voting control), and GKI can appoint members to the boards of directors of any joint stock companies formed in these sectors.

Several of these "national interest" industries are likely to require ongoing economic regulation of some of their activities after the privatization and restructuring process is completed. We refer to these industries as "natural monopolies" or "public utilities.", Other industries named in the decree are important to the national economy or national security but will not require economic regulation after privatization (vodka and wholesale trade, for example). Unlike the enterprises subject to the generic mass privatization process, privatization of the natural monopoly industries should be integrated with decisions about industry structure and regulation. Specific issues that should be addressed during the privatization process concern the horizontal and vertical expanse of these enterprises, the segments to be subject to economic regulation and those to be restructured to rely on competition, and the nature of the regulatory institutions that will govern the sectors.

In general, attempts should be made to limit the ultimate scope of regulation by separating natural monopoly segments from segments that can be structured to rely on competition. Many of these industries have expanded into activities that are completely unrelated to their primary "public utility" functions (everything from restaurants to construction companies to lumber mills). Unless a good case can be made that integration is required for the efficient operation of the enterprises delivering the primary services or that it promotes competition, these unrelated activities should be spun off to avoid having to deal with the complexities of regulating to guard against cross subsidization. ${ }^{88}$

In our view at least some activities in the electric power, telecommunications, gas pipeline and distribution, petroleum pipeline, and railroad sectors will require ongoing regulation. Portions of these industries are either regulated or owned and controlled by the government

88. For example, some of these enterprises own dedicated rail transportation facilities linking specific production facilities under their control. It may not make sense to spin off specific investments like this. 
in all developed countries. ${ }^{89}$ How much regulation and what kind will depend on the ultimate structure (horizontal and vertical) chosen for these industries and should reflect a clear recognition that the level of economic and technological development in some industries is far different from that in the United States or the United Kingdom.

Relatively little attention has been paid in Russia to the development of appropriate industry structures and effective regulatory institutions to govern these sectors both during the transition period and in the long run. This probably made sense during most of the 1992-93 period, given the need to create a sizable proreform constituency quickly and the recognition that the natural monopoly sectors pose special problems. But failure to move forward on these sectors risks their becoming a serious burden on the economy in general and on the evolution of competitive markets in particular. These sectors provide infrastructure services essential to increasing competition through expansion of product lines and geographic spheres of distribution.

Some (including until recently the GKAP leadership) have argued that the antimonopoly authorities should be responsible for regulating all industries and firms defined as natural monopolies. This would be a mistake in Russia. Despite their potential to be captured by the industries they regulate, we believe that independent agencies responsible for specific sectors would make for more effective regulation, in large part because they would be more likely to produce regulatory regimes well matched to the characteristics of each sector than would a master agency with broad responsibilities. ${ }^{90}$ Industry-specific expertise is also needed to effect desirable industry restructurings; to help to guide related government regulatory, tax, and investment policies that some of these sectors are likely to require; and to establish a framework that provides good investment incentives for the expansion and modernization of service. The AMCs should focus on competition and demonopolization programs for other sectors and play a role as advocate for

89. Economic regulation and state ownership continue to be applied to the trucking and air transport industries in some countries. We believe, however, that these industries can be competitive in Russia, as in the United States, if they are privatized with appropriate market structures. In contrast, the structure and role of the Russian railroad system would appear to make U.S.-style deregulation inappropriate, at least for some time.

90. We thus disagree with the structural recommendation of Ordover and Pittman (1992) in the Russian context. 
competition and regulatory reform in those sectors where some economic regulation appears to be necessary.

Interim arrangements for some of these sectors (particularly energy, telecommunications, and railroads) have been driven by a desire to prevent the regions and republics of the Russian Federation from taking control of facilities that happen to be located in their administrative areas. ${ }^{91}$ Efforts to stop the uncoordinated dismemberment of integrated networks of importance to the entire country are certainly understandable. We are concerned, however, that these interim arrangementslarge, complex national holding companies and sectors retained by their ministries until a restructuring plan can be negotiated-will become permanent. Moreover, issues of federal versus regional and local control in these sectors need to be addressed directly, as they have been in the United States for many years and as they are being addressed in the European Union.

Early attention must also be given to restructuring these sectors to separate natural monopoly segments from competitive segments and to create the market institutions necessary for the competitive segments to work well. Once privatization is completed and ownership shares are distributed, a major restructuring that involves significant changes in asset value will be more difficult to achieve. Good progress has been made on this score in the oil industry: several competing integrated oil production and refining enterprises are emerging, separated from pipeline transportation and product distribution enterprises. The interim structure of the electric power sector retains the possibility of creating a competitive generation sector: a holding company with the fifty largest generating plants maintained as separate subsidiaries; a national high voltage grid and dispatch centers; and regional control of distribution,

91. Under the old regime the assets of these sectors were commonly held by regional and local enterprises controlled by a branch ministry in Moscow. For example, hundreds of electricity supply enterprises used to be linked together through a planning and dispatch hierarchy whose top level was in Moscow. This system in fact depended on a decentralized hierarchy of regional dispatch centers and local generation and distribution enterprises covering progressively smaller geographic areas. Similarly, the railroad sector was organized into a large number of regional railroads whose integrated operations were coordinated from Moscow. Indeed, as a general matter it is our sense that the Russian economy was de facto much more decentralized than Western scholars have suggested (because planning worked less well than the texts suggested) and that this decentralization has helped the Russian economy to avoid an even more serious economic decline since 1990 than has been experienced. 
smaller generating facilities, and combined power and heat facilities. Little progress has been made in the other sectors to develop restructuring programs with these objectives in mind, however.

Restructuring the railroad sector is proceeding too slowly. The Russian economy depends critically on the availability of economical and efficient freight transportation service. Although the changing structure of the economy and the end of central planning are likely to lead to a shift from rail to trucks, these changes will occur relatively slowly. The existing road network simply cannot handle a large increase in longdistance truck traffic. As a result, rail transport must be restructured to support efficiently the evolving market economy. The railroad sector, however, under tight control by a ministry in Moscow, has changed little from the days of central planning. It is politically powerful and has obtained large subsidies that have enabled it to resist reform, increase employment despite a large drop in freight traffic, and ignore the changing needs of the Russian economy in its decisionmaking.

In late 1993 and early 1994, the scope of price regulation and policy toward industries with natural monopoly elements were intensively debated within the Russian government. During the course of the debate, GKAP joined GKI to support a regime in which economic regulation would be limited to classical natural monopolies and conducted by specialized agencies. General umbrella legislation embodying these principles and broadly consistent with the discussion above was approved at the deputy minister level in late February 1994. Even if it is enacted in its present form, the serious tasks of devising and implementing sound sector-specific regulatory institutions and policies will remain. Although affected enterprises may, in their own self-interest, push for the creation of predictable regulatory regimes, rapid adoption of sensible general or sector-specific policies is by no means assured in the current political climate.

\section{Conclusions}

As this paper is completed in April 1994, few observers are optimistic about Russia in the short term. The new parliament is hostile to reform and most reformers have left the government. Privatization is moving forward, but other critical structural reform is, at best, incomplete. 
We do not have an alternative, more optimistic story for the short run. But we do feel there are microeconomic grounds for optimism in the longer run. When we first began to work on structural issues in Russia in September 1992, the situation also looked hopeless. Little political support for reform could be found in the Russian government, the bureaucracy, or among powerful enterprise managers, and very little fundamental reform had been implemented. GKAP was interested in regulation, not competition. Privatization vouchers were issued to the population beginning in October 1992 amid considerable skepticism and uncertainty about the workability of the voucher auction process. Politically powerful industrial groups were making proposals for holding companies that looked like attempts to resurrect the branch ministries and turn them into long-lived private monopolies.

Enormous structural progress has been made since then. Russia has a large private sector, but it still faces the daunting task of reconstructing and reconfiguring much of its economy and its supporting legal, governmental, and regulatory institutions. Even though Russian GDP has fallen considerably since the late 1980 s, unemployment is not rampant. Because economic reconfiguration will require massive changes in employment patterns, however, a period of high unemployment of the sort experienced in Central and Eastern Europe seems inevitable. ${ }^{92}$ The more competitive Russian markets are, the more rapidly this adjustment will proceed, and the shorter the accompanying recession will be. ${ }^{93}$ The industrial structure Russia inherited and the generally procompetitive design and implementation of the Russian privatization program make the evolution to competitive markets in a reasonable time period feasible if the right policies are pursued. It remains for the antitrust authorities to turn firmly away from regulation and to become instead a strong force for competition both through their enforcement activity during and after privatization and as advocates for public policies that will support the development of an economy built on competitive markets.

It is currently fashionable in the West to focus on Russia's problems and how things might have been done differently, particularly in the

92. Because Russia still lacks an adequate social safety net, it is a very good thing that this period has been postponed thus far.

93. It is encouraging in this regard that the output of some Russian consumer product industries apparently increased substantially in 1993; see "Russian Industry: Carry on, Comrade,' Economist, January 15, 1994, p. 67. 
political sphere. But the fundamental structural changes that have begun in the Russian economy should not be overlooked. If the process of structural change is not reversed, and we do not believe it will be, Russia will move toward some sort of market economy.$^{94}$ With proper policies, that movement can be less painful than otherwise, and the resulting economy can be workably competitive. With ill-conceived policies, the journey will be painful and the destination may be very unpleasant.

\section{Appendix}

To measure industry concentrations in Russia, Goskomstat aggregations (largely five-digit codes) were used directly in the construction of the industry-level data set discussed in the text; no attempt was made to replicate individual U.S. four-digit categories. In fact, the correspondence with U.S. four-digit industries is very rough, although, on average, the Goskomstat data appear somewhat less aggregated than the U.S. data. ${ }^{95}$ Of course, there are many well-known reasons why national U.S. four-digit census industries are not necessarily relevant product markets. ${ }^{96}$

We removed electric power and resource extraction enterprises from the Goskomstat data. We also removed various repair enterprises that provided service to industrial firms, and we aggregated some Goskomstat industries to obtain manufacturing industries that are better matched

94. For examples of Russian entrepreneurship (and some long-run optimism), see Adi Ignatius, "Money to Be Made,"' Wall Street Journal, March 1, 1994, p. A1.

95. In September 1993 we discovered that three economists associated with the World Bank had independently prepared a draft study of market dominance and industrial concentration in Russian industry at a level of aggregation roughly comparable to that used here; see Brown, Ickes, and Ryterman (1993). Our data are for 1991, while theirs are for 1989. We relied on Goskomstat industry aggregations and did not try to match products into equivalent U.S. four-digit industries, while their study uses data that were apparently constructed from basic Russian product-level data to match U.S. four-digit categories. (They do not discuss how these aggregations were performed. They acquired the data from a consulting firm that apparently did not provide methodological details.) Their basic conclusions regarding concentration at the industry level are very similar to ours, despite these differences in time periods and data construction methods.

96. In particular, Werden (1988) and Pittman and Werden (1990) show that fourdigit industries are often considerably broader than markets relevant in antitrust cases. 
to U.S. four-digit industries. The resulting data set had 234 manufacturing industries, containing roughly 18,847 enterprises. In contrast, the 1987 U.S. Census of Manufactures had 459 four-digit industries. ${ }^{97}$ Several major reasons explain the difference. First, Russia simply does not produce all the products, especially all the consumer products, that are manufactured in the United States. Second, goods produced by enterprises in the military-industrial complex (including aircraft, missiles, and most computer and communications equipment) are not reported or (in the case of some consumer goods) are only partially reported. ${ }^{98}$ Finally, the way the Goskomstat data are aggregated may cause some products to be lost.

Intermediate goods produced within vertically integrated Russian enterprises are treated differently in these data than in U.S. statistics. The U.S. concentration data are built up from establishment level data, and many large U.S. firms have multiple establishments. Thus, a U.S. firm producing products in different four-digit industries at two different establishments will be represented as a supplier in both industries. U.S. firms are also supposed to report significant quantities of output of different products produced at the same establishment, if they routinely keep data in a way that makes it possible to report them, as if they were different establishments. The Russian data, however, are collected at the enterprise level, and an enterprise is simply assigned to the industry that accounts for the largest share of its production. As a result, intermediate goods produced within Russian enterprises will not be represented in the data, even though they would be if they were produced by another enterprise within the same production association or branch ministry.

Table 5 shows that there were six industries in the GKI data base for which a single firm has more than 90 percent of sales. These are generally small (as measured by reported ruble sales) and much narrower

97. The data used by Brown, Ickes, and Ryterman (1993) included 350 four-digit manufacturing industries.

98. As we understand it, an enterprise that is under a ministry within the militaryindustrial complex will report civilian production in many circumstances when civilian products are the enterprise's primary line of business. Missing from the database, however, are certain civilian products that are produced by enterprises in the militaryindustrial complex (such as civilian aircraft, computers, and certain trucks) and other products for which reporting may not be complete. 
than the four-digit industries into which they would fall if they were in the U.S. ${ }^{99}$

Table A-1 displays comparisons of the numbers of enterprises and the four-firm concentration ratios $\left(\mathrm{CR}_{4}\right)$ for sixty-seven industries in our data that appear to be reasonably well matched to specific U.S. four-digit industries, as well as leading firm market shares in each Russian industry. (The U.S. census does not report market shares for individual companies.) Although the Russian industries generally have fewer firms and higher four-firm concentration ratios, dominant firms are the exception rather than the rule.

99. For example, the production of primary tin, antimony, and mercury are listed as separate monopoly industries in the GKI data. The U.S. SIC system would group them together with several other metals in an industry called "primary production of nonferrous metals" - probably because of their relatively small value added rather than because these metals are good substitutes on the demand or supply sides. Similarly, iodine and bromine production is listed as a separate industry with a single producer in the Russian data. If this producer had been a U.S. company, it would have been grouped together with other firms into a four-digit industry called "industrial inorganic chemicals, not elsewhere classified." Other monopolies that appear in the Russian data are for plastics, synthetic fiber, and machine construction classifications that are far narrower than the U.S. four-digit level; these include, for instance, synthetic fibers with glass supports, agricultural machinery for distributing forage, and cleaning and dust collector equipment. A few industries are more aggregated than are the corresponding U.S. fourdigit industries; these include tobacco products and meat products. 


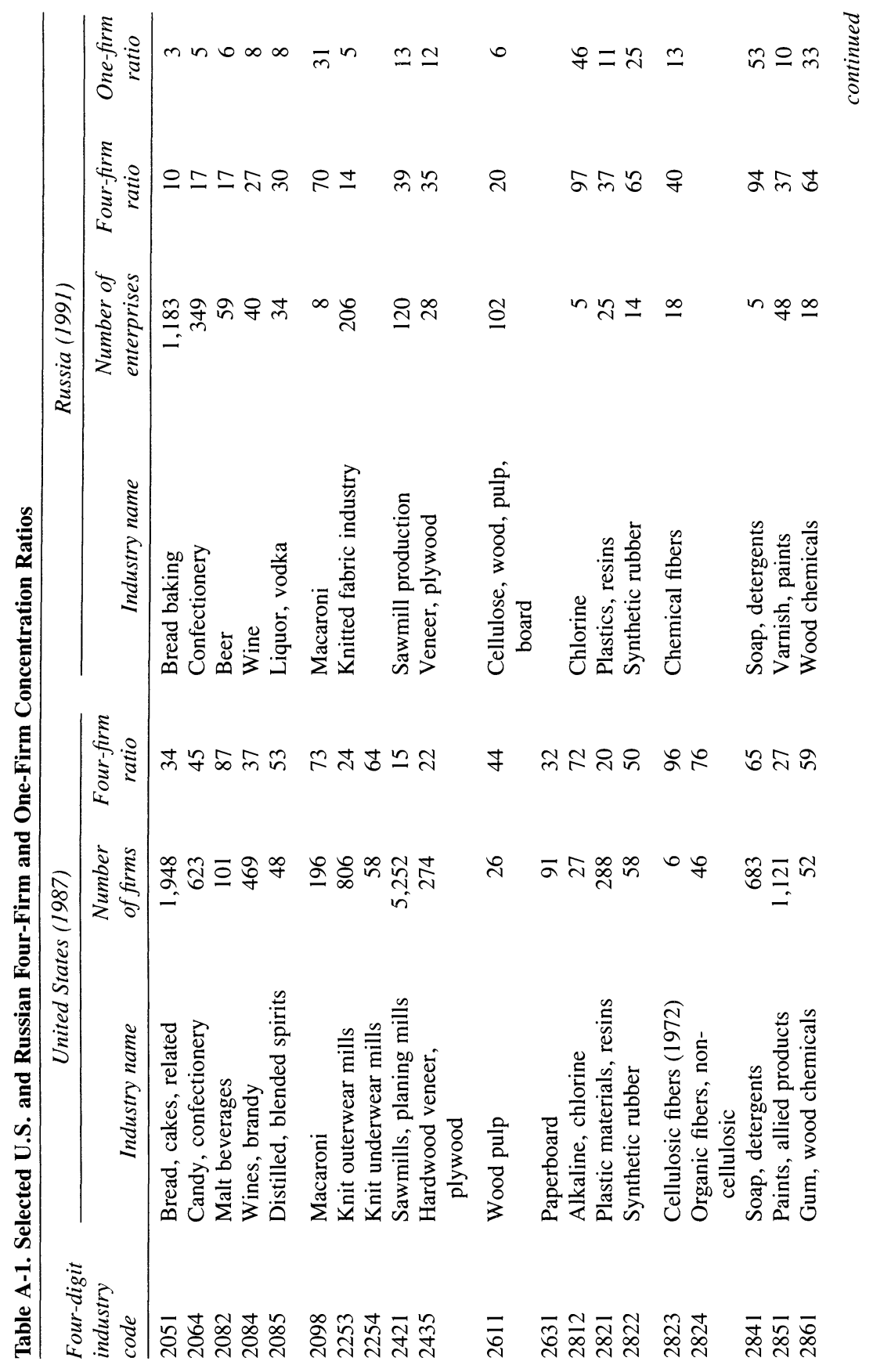




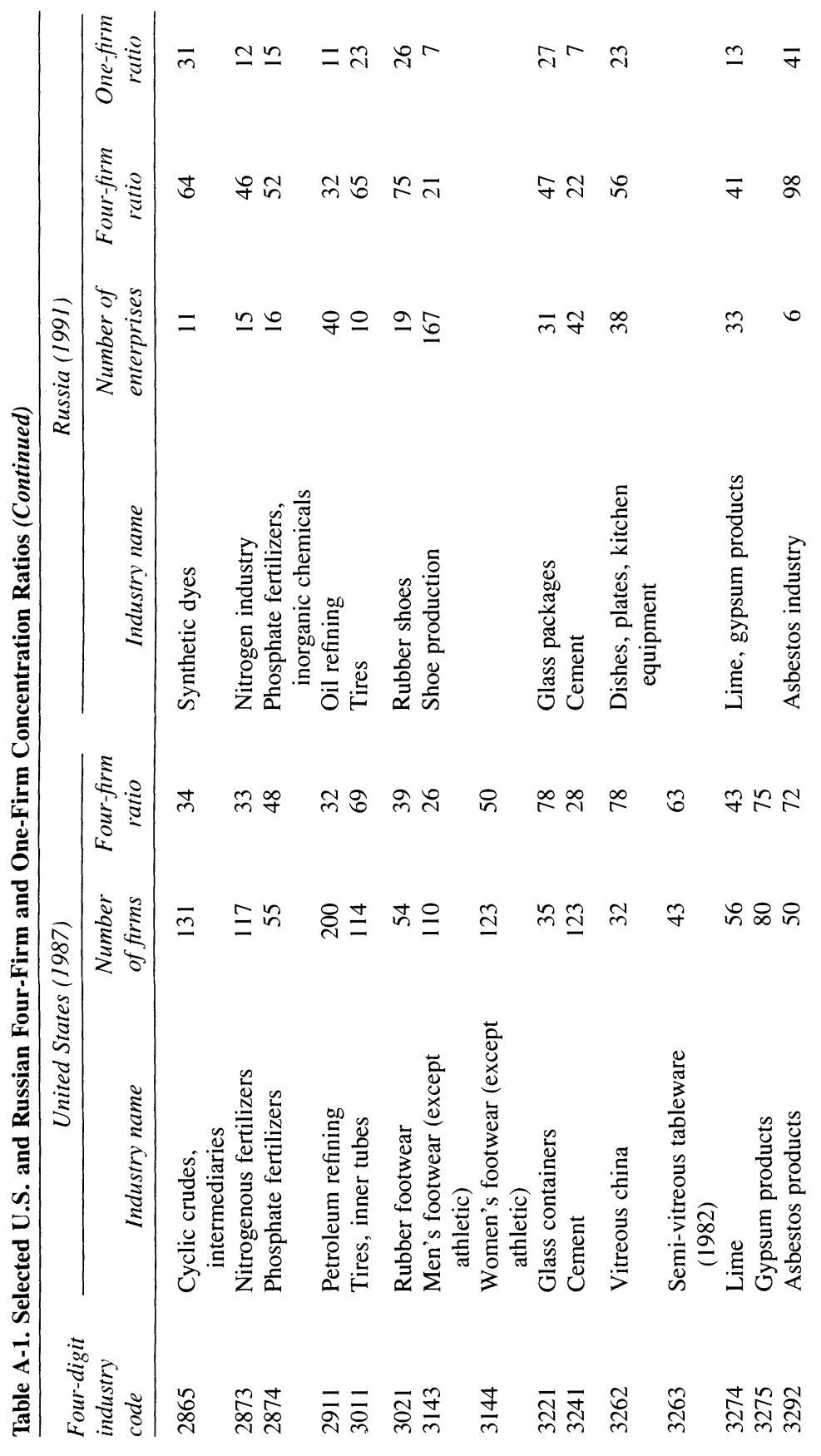




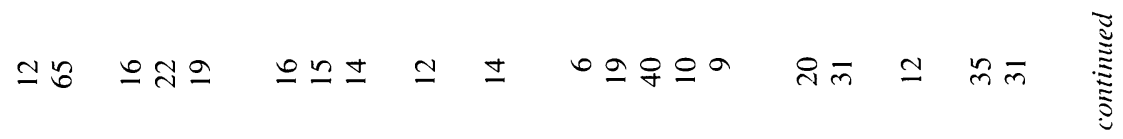

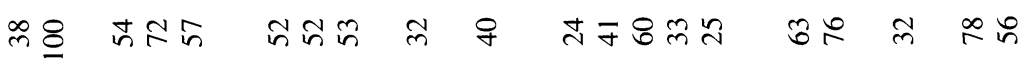

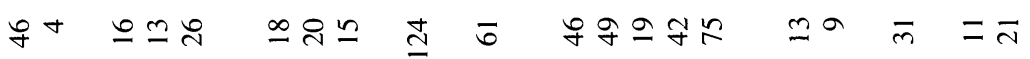

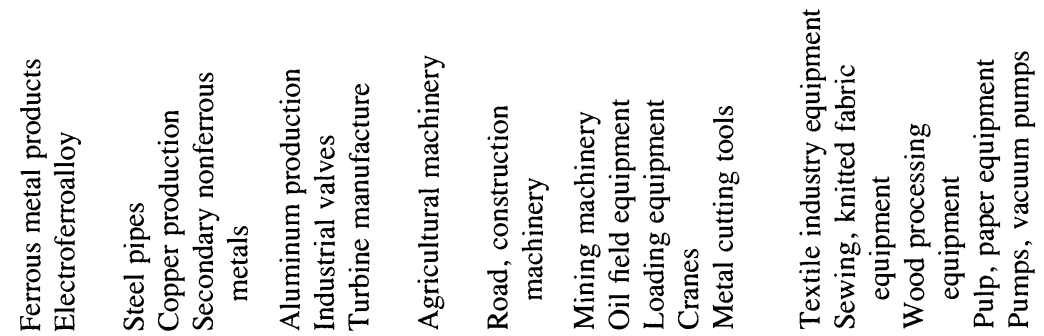

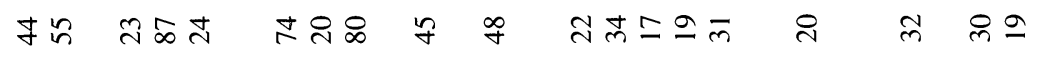

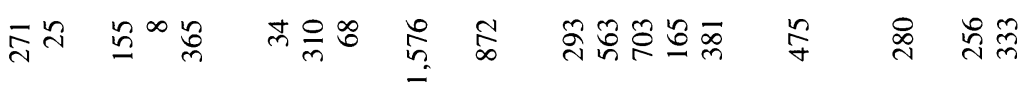

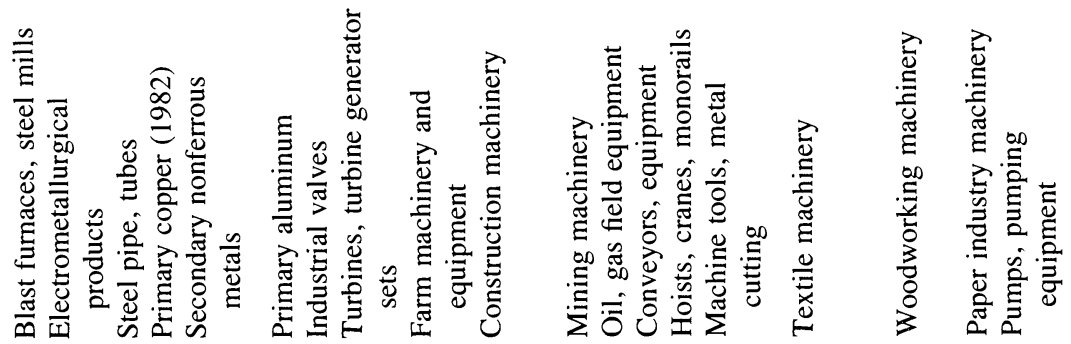

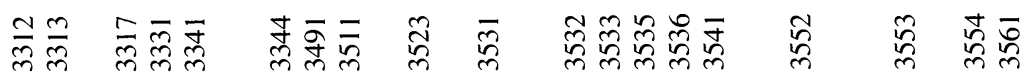




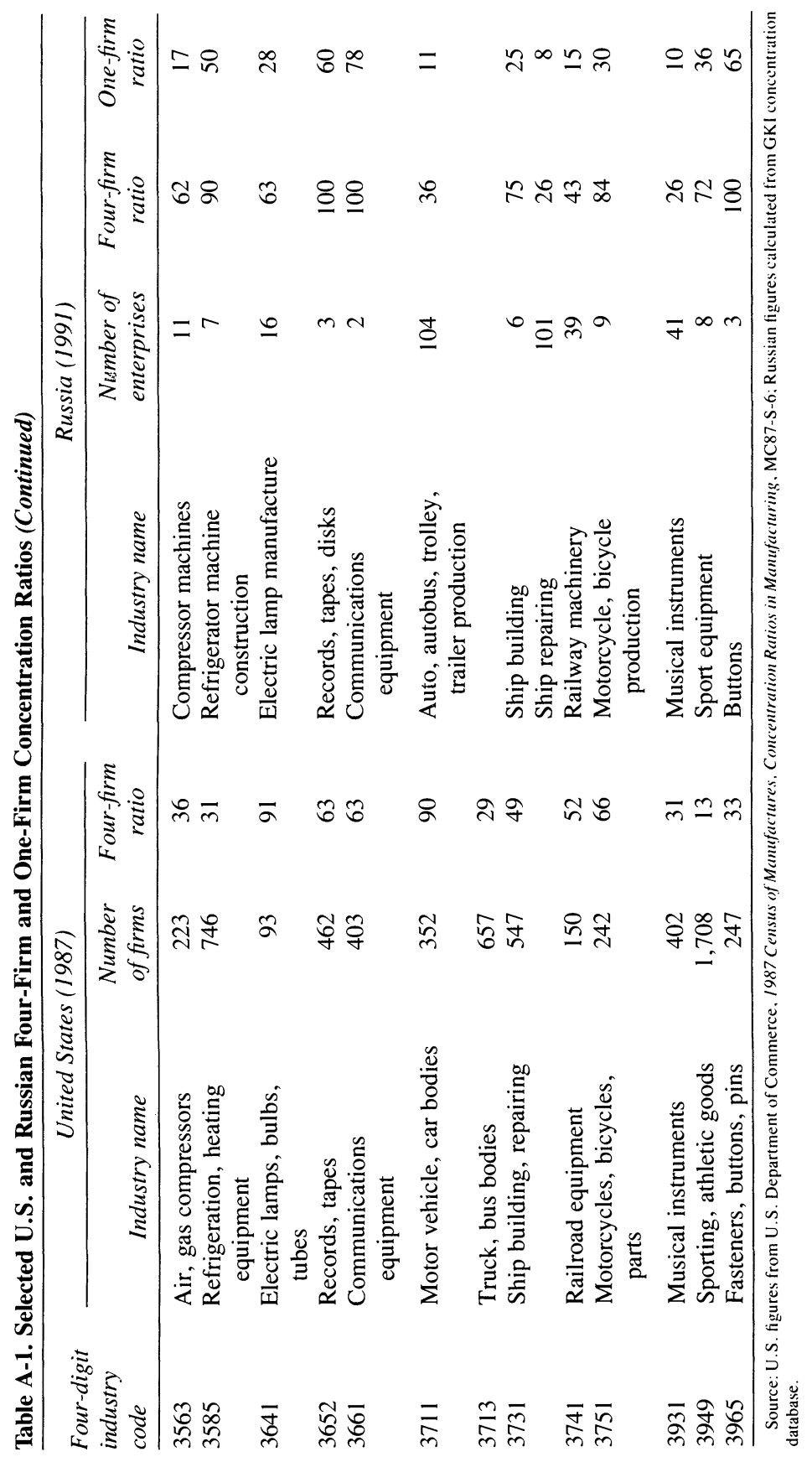




\section{Comments and Discussion}

Comment by Andrei Shleifer: The paper by Joskow, Schmalensee, and Tsukanova is likely to become the standard reference for future students of industrial organization in Russia as well as for policy advisors whose interests include competition policy. The paper is thorough, detailed, and extremely well written. I agree with their analysis, although I am less optimistic that future policy in Russia will foster rather than deter competition.

The instincts of most Russian politicians do not bode well for the future of competition. The sentiment for protection is strong at both the national and the local level. The automobile industry received protection the minute it asked, without much argument for competition from anyone. The banking industry received protection from foreign competition as well, from none other than the liberal Finance Minister Fyodorov. Local governments stand ready to protect their local industries from imports from other parts of Russia and have done so on some occasions. The main reason that competition in product markets, including that from imports, is intensifying is that government officials cannot control the flows of trade. At the moment, Russian borders are just too porous.

Nor are the proposals for the formation of financial industry groups in any way dead. In many industries the idea of consolidating all firms into one trust-like structure is alive and well. One of the most dangerous areas where such proposals are attracting attention is agriculture, where several regional governments have created regional agroindustrial groups that control the production and distribution of agricultural commodities in the region. The problem with such trusts is twofold. First, 
because of their market share, they can and do raise prices. Second, because of their importance for the national and regional economies, the trusts are much more effective than smaller firms in extracting subsidies from the government. In an important way the monopoly problems identified by Joskow, Schmalensee, and Tsukanova are responsible for the rapid credit expansion and the resulting inflation in Russia.

It is difficult to predict what the future holds. Credit policy has been tightening in the first quarter of 1994, with the result that many large firms are no longer capable even of paying their workers. This has already led to calls for consolidation of some industries to reduce capacity and will undoubtedly further increase the pressures toward government-created monopolies. After all, protection is just a cheap way for a government to subsidize inefficient firms. At the same time, many firms in Russia are restructuring following privatization and, in particular, are trying to diversify their product lines. As the authors observe, the Russian firms have been too specialized under socialism and are quite capable of producing broader arrays of goods. In addition, in some industries, new firms are begining to enter. The fundamental question is whether the forces of competition that have been unleashed by the Russian reform will work faster than the political forces that usually resist competition. I believe that the fundamental item on the antimonopoly policy agenda in Russia is to stall politicians who want to create monopolies and thus to allow competition to work its ways.

General Discussion: Several participants were skeptical of the authors' sanguine view of the future of competition in the Russian economy. Their optimism, Garth Saloner said, rests largely on the presumption of supply-side substitutability, where specialized organizations will recognize that they have capabilities and resources that can be used to produce a wide variety of other products. Ultimately, that should lead to increased competition. According to Saloner, however, other forces are at work in the Russian economy that could pull in the opposite direction, toward restricting competition.

First, Saloner said, those firms that have first-mover advantages should eventually be able to use branding to secure their market positions before their rivals can gain strong market footholds. Second, new entrants would have to find access to vertical supply, a difficult prop- 
osition considering the high levels of vertical integration in the Russian economy. Third, firms that are the first entrants in particular markets should have some learning advantages over rivals even if these first firms are less competent. Fourth, firms in narrow markets have tremendous incentives to collude by not entering one another's product markets.

Nancy Rose suggested that supply-side substitutability would probably be low in many industries with dedicated single product plants. Taking examples from the paper, she noted that one factory produces 93 percent of all the cement mixers in Russia, while another produces 75 percent of all road-building cranes, and partial conversion of these plants to other products seems unlikely. Although conceding that transforming a factory from producing whole wheat bread to white bread or from women's dresses to men's pants was probably easy, she argued that converting plants with more well-defined, product-specific capital stocks to anything approaching modern flexible manufacturing techniques would be very difficult. Rose also maintained that the lack of an efficient transportation network poses constraints to competition. So too does the lack of a well-defined distribution channel; existing firms tend to have their own dedicated distribution networks.

Fred Pryor argued that the four-digit concentration ratios presented in the paper are not very meaningful because of the enormous amount of vertical integration characteristic of the Russian industrial structure. He said that Russian input-output tables, which provide information on the distribution of product by industry, must be used to determine genuine levels of competition. Pryor also noted that an old article from the Review of Economics and Statistics had provided evidence that the best predictor of a concentration ratio in a particular industry in a given country is the ratio for that industry in the United States. According to his calculations based on the paper's data, there is zero correlation between concentration ratios in Russia and those in the United States. This suggests a shakeout in Russian industry during the next decade, he said, assuming that firms are moving toward optimal size. Therefore, he concluded, the authors should discuss the Russian procedures for merging companies and spinning off operations, activities that would play a role in reaching optimal industrial structure.

Richard Ericson argued that the restructuring of the Russian economy could be less a product of mergers and dissolutions of existing firms 
than of a radical reconfiguration of economic activity. Ericson noted that economic sectors such as marketing, financial services, and external financing did not really exist during the Soviet period, while others such as transportation and trade were underdeveloped. New activity in these areas, he said, would be an important source of entry into the Russian economy, making the issue of deconcentration of existing industries less important than some have asserted.

Ericson also argued that Russian industry has a deep structural problem involving the capabilities of the current configuration of labor, capital, land, and resources inherited from the Soviet Union. He suggested that a large portion of Soviet industry had been net-valuedestroying, producing things essential to keep other parts of the centrally planned economy operating. Firms had sole suppliers and sole users, but this chain was broken after the fall of the Soviet Union and the introduction of market reforms, causing the breakdown of the entire system. One of the more important results, he said, is that many firms cannot cover their costs of operation. In addition firms can no longer provide full employment to the existing labor supply.

The connection between property rights and economic restructuring in Russia was also discussed. Ericson said that uncertainty over property rights has been limiting the restructuring of Russian industry despite substantial privatization. He said that local regulatory agencies continue to dictate, both directly and indirectly, much of the activity of privatized firms. In addition, he suggested, there is less separation between the bureaucracy and newly privatized enterprises in Russia than there has been in Europe. And because firm owners do not have full property rights, he contended, they are unable to consider sufficiently fundamental restructuring programs.

Ericson added that because existing firms control the vast majority of labor, capital, material, and technological resources, their managers and workers have an incentive to maintain the status quo and avoid restructuring. Large state enterprises have an additional disincentive to restructure, he said, in that they control huge tracts of valuable land near major population centers that they use inefficiently and unproductively, for example, to store waste or to farm to provide their employees with inexpensive food supplies. Restructuring would almost certainly require this land to be used more productively. Peter Pashigian said that Russian firms may face disincentives to develop new products if they 
are unable to exercise control over their intellectual property by receiving enforceable patents, trademarks, and copyrights. He suggested that the authors add to their paper a discussion of the current state of protection of intellectual property rights in Russia.

Several participants suggested that by focusing exclusively on the domestic Russian economy, the authors overlooked foreign influences that may help overcome the kinds of market failures outlined in the paper. Pashigian argued that foreign producers are a potentially important source of competition in the Russian economy. It is therefore important to know, he said, whether Russian industrial associations are so powerful that they can squelch international competition by controlling tariff levels and imports. Elizabeth Bailey argued that the virtual absence of accepted accounting systems makes it difficult to monitor the performance of Russian firms. She said that alliances between Russian and Western firms might result in the introduction of the kinds of standards that are necessary to monitor firm performance and, ultimately, force firms to operate more efficiently. 


\section{References}

Boston Consulting Group (BCG). 1993. Food Distribution in Russia. Unpublished report prepared for GKI and the U.S. Agency for International Development. London.

Boycko, Maxim, Andrei Shleifer, and Robert W. Vishny. 1993. "Privatizing Russia." Brookings Papers on Economic Activity, 2: 139-92.

Brown, Annette N., Barry W. Ickes, and Randi Ryterman. 1993. "The Myth of Monopoly: A New View of Industrial Structure in Russia." World Bank, Washington. October.

Chandler, Alfred D., Jr. 1977. The Visible Hand: The Managerial Revolution in American Business. Cambridge, Mass.: Belknap.

Cooper, Julian. 1986. "The Civilian Production of the Soviet Defence Industry." In Technical Progress and Soviet Economic Development, edited by Ronald Amann and Julian M. Cooper. Oxford: Blackwell.

- 1991. The Soviet Defence Industry. New York: Royal Institute of International Affairs.

Coopers \& Lybrand. 1993. Preliminary Advice on the Practical Application of Competition Policy in Russia. Unpublished report prepared for the Russian Antimonopoly Committee. March.

Freris, Andrew. 1984. The Soviet Industrial Enterprise. St. Martin's Press.

Hewett, Ed A. 1988. Reforming the Soviet Economy. Brookings.

Hewett, Ed A., and Victor Winston. 1991. Milestones in Glasnost and Perestroyka. Brookings.

Holt, Jane. 1993. Transport Strategies for the Russian Federation. Washington: World Bank.

International Finance Corporation (IFC). 1993. Trucking Privatization in Russia: The Nizhny Novgorod Model. Washington.

International Monetary Fund (IMF). 1991. A Study of the Soviet Economy. Vol. 3. Washington.

$\rightarrow$ Joskow, Paul L. 1988. "Asset Specificity and the Structure of Vertical Relationships: Empirical Evidence." Journal of Law, Economics and Organization 4 (Spring): 95-117. Reprinted in The Nature of the Firm, edited by Oliver E. Williamson and Sidney Winter. Oxford University Press, 1991.

Katz, Barbara. 1977. “' 'Gigantism' as an Unbalanced Growth Strategy: An Econometric Examination of the Soviet Experience 1928-1940." Soviet Union. 4 (2): 205-22.

Kroll, Heidi. 1991. "Monopoly and Transition to the Market."' Soviet Economy 7:143-74.

Lainela, Seija, and Pekka Sutela. 1993. "Russian Privatization Policies." In The Russian Economy in Crisis and Transition, edited by Pekka Sutela, 81110. Helsinki: Bank of Finland. 
Lawrence, Paul R., and others. 1990. Behind the Factory Walls: Decision Making in Soviet and US Enterprises. Boston: Harvard Business School Press.

Ordover, Janusz A., and Russell W. Pittman. 1992. "Competition Policies for Natural Monopolies in a Developing Market Economy." Discussion Paper EAG 92-9, Antitrust Division, U.S. Department of Justice. November.

Petrov, Andrei. 1993. "Privatization and Antimonopoly Policy." RFE/RL Research Report 2 (July 23): 19-22.

Pittman, Russell. 1992. "Some Critical Provisions in the Antimonopoly Laws of Central and Eastern Europe."' The International Lawyer 26 (Summer): 485-503.

Pittman, Russell, and Gregory J. Werden. 1990. "The Divergence of SIC Industries from Antitrust Markets: Indications from Justice Department Merger Cases." Economics Letters 33 (July): 283-86.

Schmalensee, Richard. 1992. "Sunk Costs and Market Structure: A Review Article." Journal of Industrial Economics 40 (June): 125-34.

Spulber, Nicolas. 1991. Restructuring the Soviet Economy. University of Michigan Press.

Sutton, John. 1991. Sunk Costs and Market Structure: Price Competition, Advertising, and the Evolution of Concentration. MIT Press.

Tirole, Jean. 1991. "Privatization in Eastern Europe: Incentives and the Economics of Transition." In The NBER Macroeconomics Annual 1991, edited by O. Blanchard and S. Fischer, 221-58. MIT Press and National Bureau of Economic Research.

Tsapelik, Vladimir, and Evgeny Yasin. 1990. "Puti Preodoleiya Monopolisma v Obshestvennom Proizvodstve." Planovoye Khosiaistvo No. 1 (January): $35-41$.

Werden, Gregory J. 1988. “The Divergence of SIC Industries from Antitrust Markets: Some Evidence from Price Fixing Cases." Economics Letters 28 (2): 193-97.

Williamson, Oliver. 1975. Markets and Hierarchies. Free Press.

- 1985. The Economic Institutions of Capitalism. Free Press.

World Bank. 1992. Russian Economic Reform: Crossing the Threshold of Structural Change. Washington: World Bank. 